Article

\title{
Late Pleistocene Post-Glacial Sea Level Rise and Differential Preservation of Transgressive "Sand Ridge" Deposits in the Adriatic Sea
}

\author{
Domenico Ridente ${ }^{\mathbb{D}}$ \\ Istituto di Geologia Ambientale e Geoingegneria (CNR-IGAG), UOS Sapienza Università di Roma, \\ Piazzale Aldo Moro 5, 00185 Rome, Italy; domenico.ridente@igag.cnr.it; Tel.: +39-06-4991-4153
}

Received: 7 December 2017; Accepted: 6 February 2018; Published: 8 February 2018

\begin{abstract}
Linear sand bodies with ridged or mounded morphology are commonly referred to as "sand ridges". Their origin may reflect a great variety of depositional processes and environments, although many examples from modern shelves include near-shore transgressive deposits formed during the last post-glacial sea level rise. These transgressive sand ridges, however, are not present on all the margins drowned during this interval, indicating that local environmental factors contribute to their formation and preservation. Transgressive sand ridges are recognized on the South Adriatic shelf in water depths between 90 and $120 \mathrm{~m}$, where they overlay a major unconformity originated during the last glacial sea level fall and lowstand. In contrast, they are absent on the Central Adriatic shelf, where transgressive deposits above the glacial unconformity fill erosional scours without forming relief on the seafloor. The transgressive sand ridges on the South Adriatic shelf appear roughly elongated parallel to the bathymetric contour and are locally as thick as $15-20 \mathrm{~m}$. Core data indicate an overall coarse-grained composition, with a relevant bioclastic component. Their limited distribution reflects the importance of local variation in shelf morphology and sediment sourcing at the onset of sea level rise. In particular, their deposition and preservation are favored in less subsiding shelf sectors characterized by higher gradients and tectonic relief, where transgressive erosion and reworking of pre-existing lowstand deposits is also more efficient.
\end{abstract}

Keywords: Quaternary sequences; sea level cycles; seismic stratigraphy; shelf erosion

\section{Introduction}

Shelf deposits with overall sandy composition, wedged and/or mounded shape, and along-strike extent over tens of kilometers, are known from ancient and modern continental margins [1-15]. These deposits include sedimentary bodies formed in different environments by different processes; they range in scale from thick (tens of meters) prograding wedges $[16,17]$ to smaller $(1-3 \mathrm{~m})$ bedforms [18]. They have been also variably termed: "offshore bars", "sand ridges", "offshore sand deposits", "sand banks", "near-shore bars", and "barrier islands". Despite differences in the way their genesis has been interpreted, they all share the common feature of requiring mobilization and deposition of coarse sediment $[9,19]$, in order to form linear, elongated depocenters roughly parallel to the morpho-bathymetric contour.

The term "offshore bar" was used early to define outer shelf sand bodies from ancient settings typically encased by "shales"; their genesis was interpreted as sand bodies forming at depths beyond the shoreface to inner-shelf transition, under the control of long-shore currents and physiography [20-24]. Following the advent of sequence stratigraphy and the emphasis on sea level change, most "offshore bar deposits" were re-interpreted as "sharp-based" lowstand shorefaces [25-28]. In this new light, their origin was supposedly controlled by sea level fall and shoreline migration onto previous outer shelf sediment, rather than by offshore currents on a distal shelf environment. 
In some cases, however, comparable deposits have been interpreted as transgressive shoreface deposits forming during sea level rise [29-31].

Analogue deposits on modern continental shelves have been similarly interpreted as "relict shoreface deposits" formed during phases of lowstand to sea level rise [8,10-12,32-37]. Such reworked shoreline deposits have often been referred to as "transgressive sand ridges" [16,38,39], typically formed during the last post-glacial transgression.

This work documents the occurrence and lateral variability of transgressive "sand ridge-like" deposits (hereinafter TSR) on the Adriatic shelf by mapping their depocenters and integrating seismic and core stratigraphy. These deposits are preferentially located in the southern part of the Adriatic Sea, at water depths between -90 and $-120 \mathrm{~m}$ (Figure 1). In the Central Adriatic (south of the Mid Adriatic deep (MAD), Figure 1), at the same depth, transgressive deposits thin and pinch-out, leaving place to patchy or tabular deposits that fill morphological lows of the underlying erosional unconformity (in a sense resembling the "healing phase" of early sequence stratigraphy models [40]).

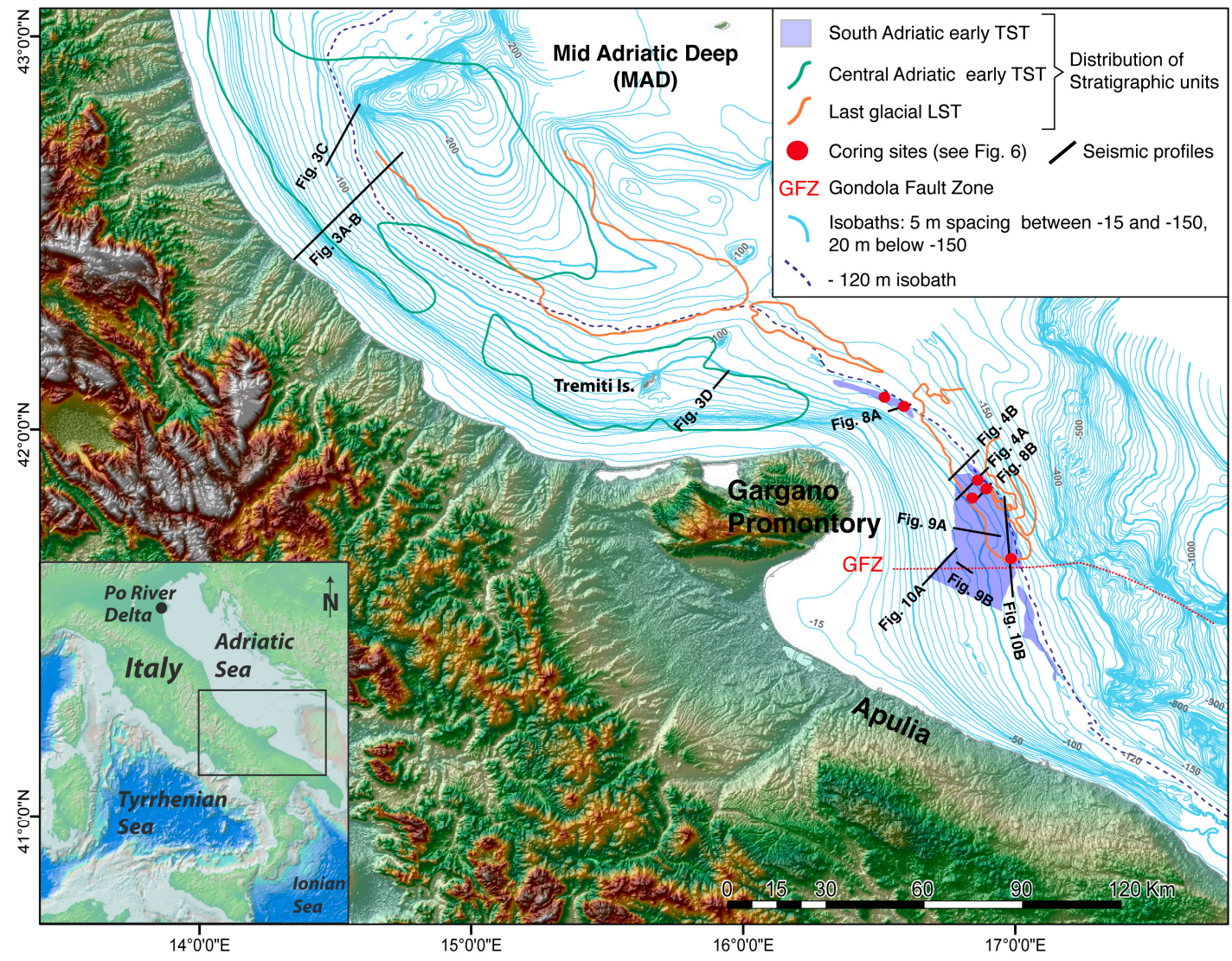

Figure 1. Study area and location of the South Adriatic early transgressive (TST) unit containing transgressive sand ridge deposits (the DTM is from NASA SRTM data). The distribution of early TST deposits in the Central Adriatic and of the last glacial lowstand (LST) are also shown, together with location of seismic profiles and core sites. Note the Gondola Fault Zone (GFZ) deforming the South Adriatic shelf and deeper basin. The abrupt termination of the area of distribution of the early TST, south of the GFZ, reflects the limitation of data available for this study.

The aim of this work is to trace a relationship between the locally different depositional/ preservation potential of these deposits (as evidenced by their geographical distribution) and the variability of shelf morphology and sediment sourcing; these are in turn controlled by changes in the tectonic setting and depositional environment from north to south along the Adriatic margin. 


\section{Geological Setting and Stratigraphic Background}

The Adriatic Sea is an overall mud-dominated basin [41,42], characterized by marked variability in the shelf and slope setting [43,44]. The Po River is the main sediment entry point [45], located on the shallow, $100 \mathrm{~km}$ wide North Adriatic shelf (Figure 1). The North Adriatic shelf edge borders a small, remnant basin ca. $260 \mathrm{~m}$ deep (MAD in Figure 1), which is the deepest zone of the Central Adriatic; a deeper basin (up to $-1200 \mathrm{~m}$ ) develops in the South Adriatic, corresponding to the area south of the Tremiti Islands and Gargano Promontory (Figure 1).

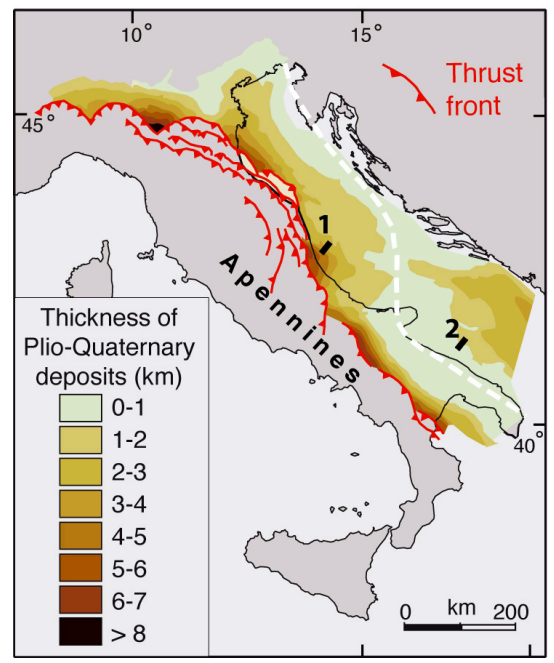

A)

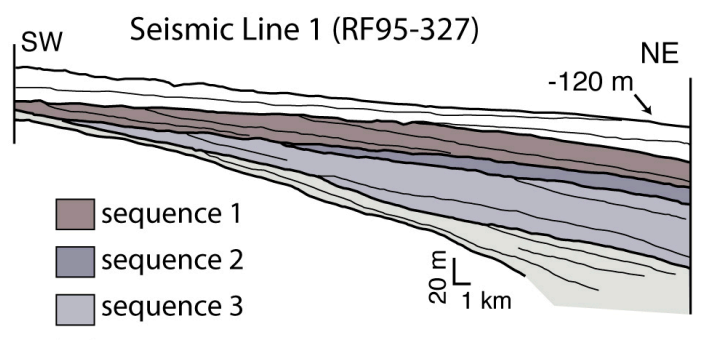

sequence 4

SW Seismic Line 2 (YD-15)

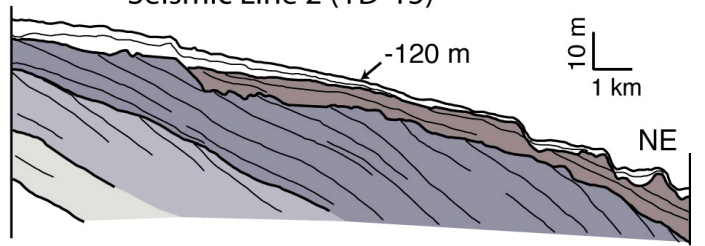

B)

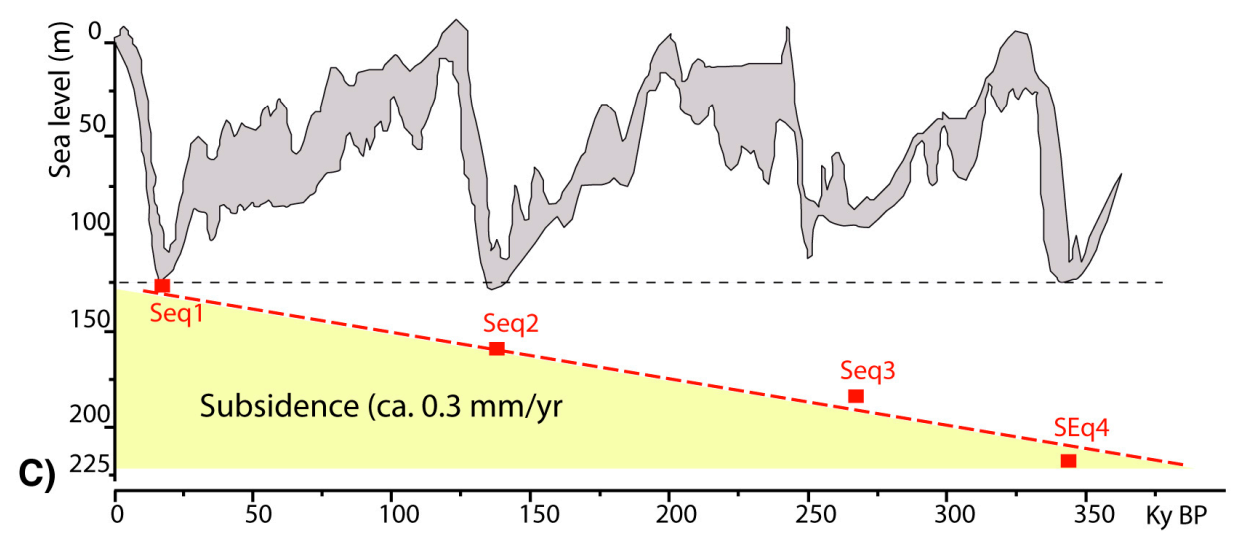

Figure 2. (A) (modified from [46]): The Adriatic Sea is part of the Apennine foreland basin, where sectors affected by greater subsidence were filled by foredeep deposits since the Pliocene. The depocenters of these foredeep deposits thin towards the flexural bulge (white dashed line), evidencing areas with contrasting rates of tectonic subsidence (greater along the North-Central Adriatic shelf) and uplift (greater along the South Adriatic shelf). (B) These regional tectonic trends are reflected by the vertical stacking pattern of depositional sequences recording ca. 100 ky glacio-eustatic cycles: sequences display a back-stepping geometry (i.e., landward shift) from oldest sequence 4 to sequence 1 in the Central Adriatic (Line 1). In contrast, the sequences show a fore-stepping trend in the South Adriatic, where lower subsidence and/or uplift prevail during the same interval [44,48]. (C) (Modified from [54]): Average subsidence rates of $0.3 \mathrm{~mm} / \mathrm{y}$ in the Central Adriatic have been derived by comparing the depth of lowstand shorelines for each sequence (red rectangle) with sea level curves (enveloped as a grey field) reconstructed by different authors [61-65]. This value is twice the average sediment supply estimated for the same interval [54], thus allowing for a renewal of accommodation space during each cycle and promoting the back-stepping of sequences. 
This contrasting morpho-bathymetric setting reflects the structural evolution of the Adriatic Sea as part of a foreland basin (Figure 2A) variably deformed since the early Cenozoic [46-52]. Quaternary stratigraphy therefore results from the interplay between high-frequency (ca. $100 \mathrm{ky}$ ) glacio-eustatic cycles, variable tectonic subsidence, inherited tectonic relief $[44,45,53,54]$, and uneven distribution of riverine sediment sources, concentrated north of Gargano Promontory [55-57].

The stratigraphic succession recording shelf and slope deposition consists of depositional sequences largely composed of progradational units few tens of meters thick and laterally continuous over hundreds of kilometers around Gargano Promontory [55-60]. These sequences reflect high-amplitude $(100-120 \mathrm{~m})$ sea level oscillations during the last four $100 \mathrm{ky}$ glacio-eustatic cycles [61-65]. As a whole, the set of sequences forms a composite shelf wedge with an overall back-stepping architecture north of Gargano Promontory, and a fore-stepping stacking pattern to the south (Figure 2B). These contrasting stacking patterns reflect the higher subsidence rates and faster renewal of accommodation space north of Gargano Promontory (Figure 2C).
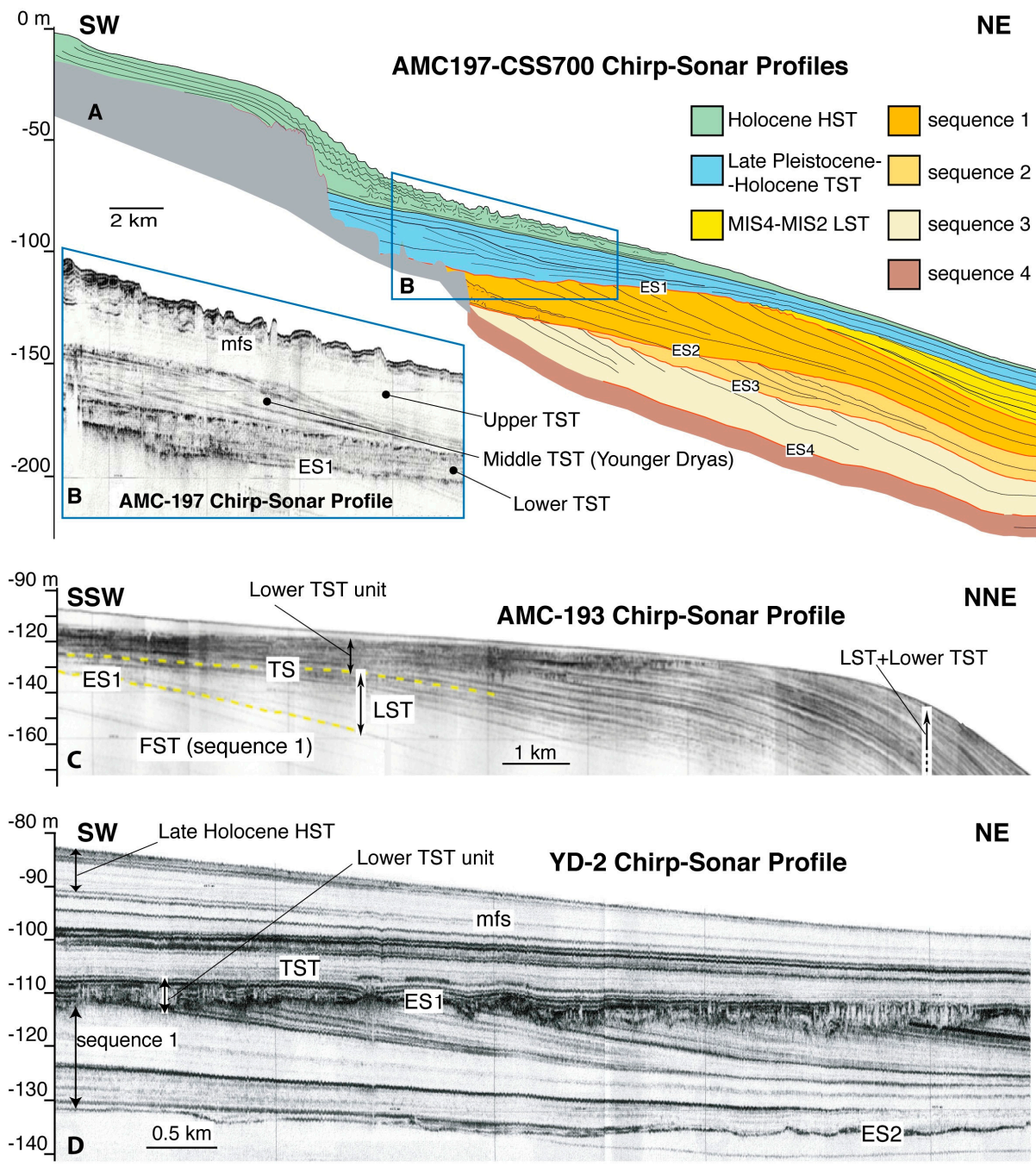

Figure 3. Stratigraphic architecture and lateral variability of Upper Pleistocene-Holocene units in the Central Adriatic (location of profiles in Figure 1). Four sequences separated by erosional unconformities (ES1-ES4) record as many 100-ky glacio-eustatic cycles ((A) modified from [58]). Above unconformity ES1, capping the youngest sequence 1, post-glacial TST and highstand (HST) deposits are present ((B-D); $\mathrm{mfs}=$ maximum flooding surface). The TST shows a vertical tripartition $(\mathbf{B})$, with a lower TST unit characterized by high lateral variability from north (C) to south ((D) modified from [43]), moving away from the main Po River sediment source. 
The entire succession has been age-constrained based on the calibration of seismic stratigraphy with a set of multi-proxy chronological data derived from conventional cores and borehole data. These include $\delta^{18} \mathrm{O}$ records from planktic and benthic foraminifera, magneto-stratigraphy, calcareous nannoplankton bioevents and ${ }^{14} \mathrm{C}$ dating $[55,58,60,66,67]$. Accordingly, the four sequences (numbered 1-4 top-down and bounded by erosional unconformities ES1 to ES4) formed between ca. 400 and 18-20 ka BP; the overlying units consist of post-last glacial transgressive (TST, between 18-20 and $5.5 \mathrm{ka} \mathrm{BP}$ ) and highstand (HST, from $5.5 \mathrm{ka} \mathrm{BP}$ to present) deposits (Figure 3).

Lowstand deposits of the Last Glacial Maximum (LGM) are largely confined within the wide northern shelf and into the MAD (Figure 3A,C), where the paleo-Po River directly fed pro-delta progradation, resulting in a $>200 \mathrm{~m}$ thick lowstand wedge [68]. South of the MAD, lowstand deposits correspond to a shelf edge progradational unit formed at the end of deposition of sequence 1 (Figure 4). This shelf edge last glacial lowstand (LST) is only few tens of meters thick, with depocenters becoming thinner and more irregular south of Gargano Promontory (Figure 5).
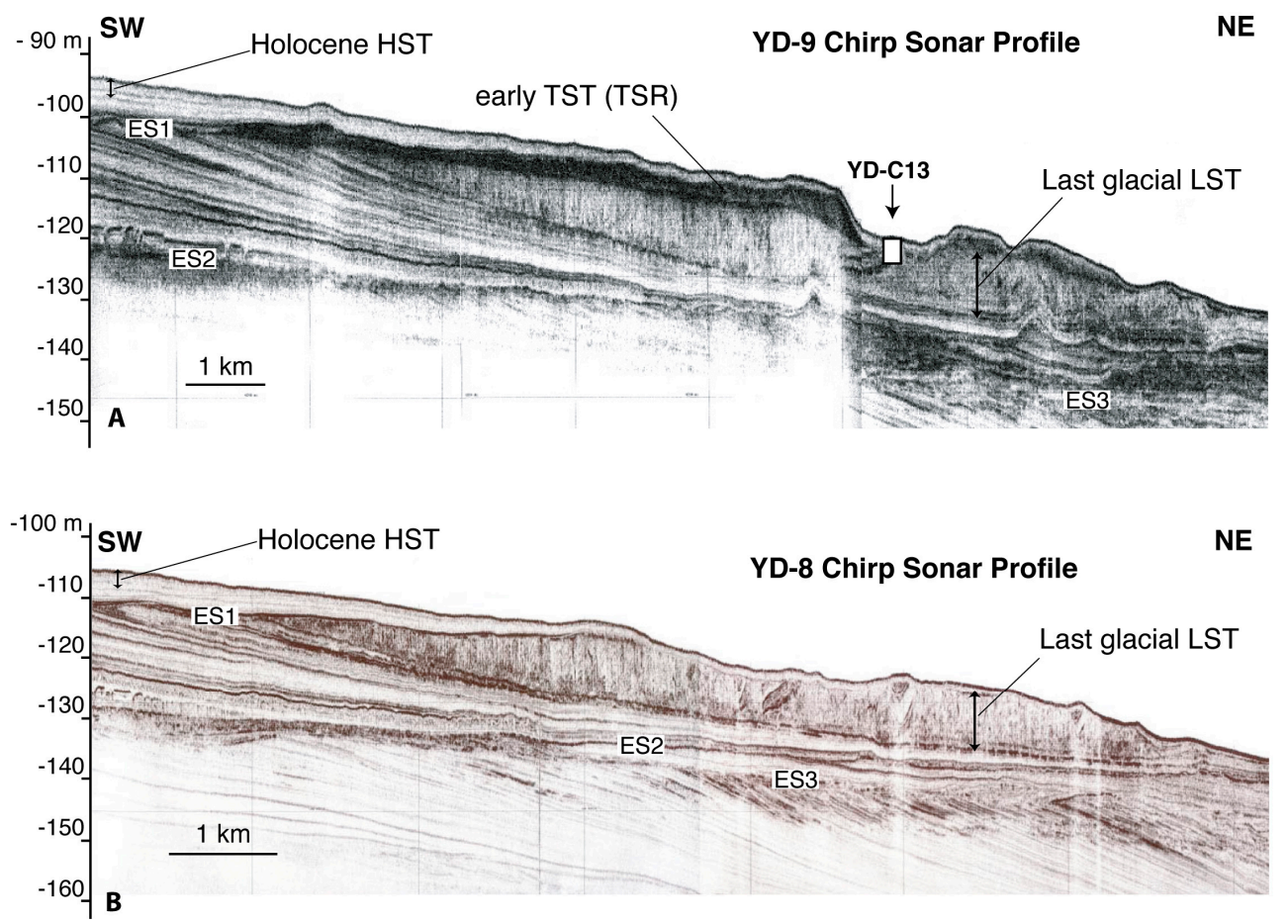

Figure 4. Seismic profiles YD-9 (A) and YD-8 (B) show the last glacial LST on the South Adriatic outer shelf (modified from [56]; location in Figures 1 and 5). This corresponds to the most distal progradational unit within sequence 1 (encompassed by ES1 and ES2), formed at the end of the last glacial sea level fall. This shelf edge LST consists of a lenticular wedge with a patchy distribution (Figure 5), rapidly passing to a thin draping veneer at depths greater than 130-140 m. Note the opaque seismic facies, sharp basal contact and erosional top surface (with channel incision in YD-9), indicating marine erosion and reworking. An early TST unit is present only in YD-9 seismic profile (A), which correlates with deposits to the south interpreted as transgressive sand ridges (TSR). The absence of this unit in YD-8 seismic profile (B) marks the northern limit of the TSR distribution area. The target of core YD-C13 is also reported (compare with Figures 5-7).

Post-glacial deposits overlying sequence 1 include a Late Pleistocene-Holocene TST and a late Holocene HST [56,69] (Figure 3); the TST displays vertical and lateral variability, from early to late sea level rise and from north to south, respectively. Only on the Adriatic shelf north of the MAD is the progressive sea level rise recorded by the back-stepping of barrier-lagoon systems [70-72]. On the Adriatic shelf south of the MAD, the TST is characterized by the stacking of three distinct 
units [66,73-75] (Figure 3). The upper or late TST unit is composed of laterally continuous, very low angle to flat seismic reflectors, gradually passing into the overlying HST progradational sigmoid (Figure 3). The middle TST unit shows a general progradational pattern on the inner shelf and has been related to a phase of increased sediment flux during the Younger Dryas cold reversal [73]. The lower or early TST unit lays directly on the erosional unconformity (ES1) capping sequence 1, resulting in the most laterally discontinuous and heterogeneous from north to south (Figure 1).

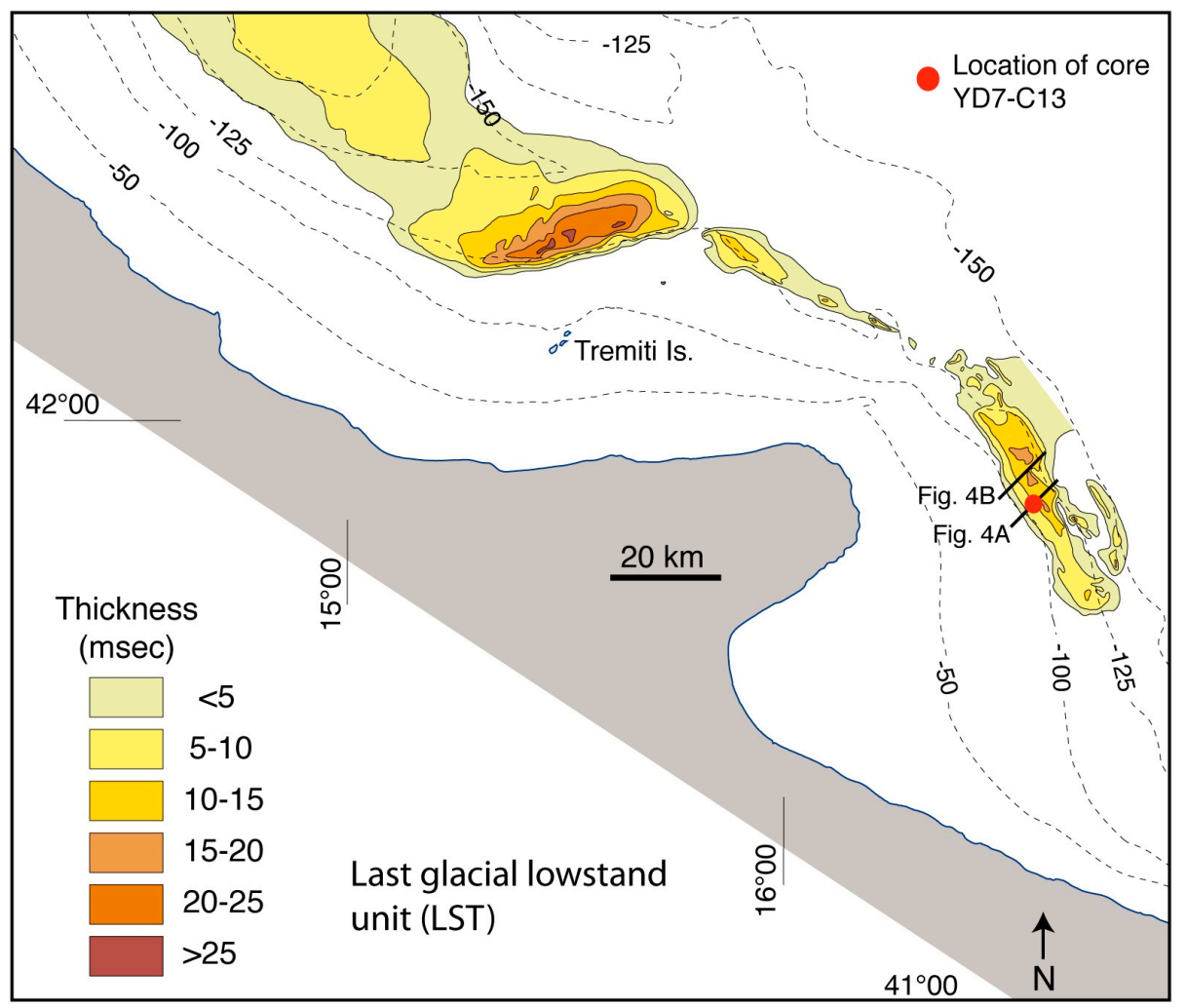

Figure 5. Isochronopachs ( $1 \mathrm{msec} \cong 0.75 \mathrm{~m}$ in the investigated interval) of the last glacial LST shown in Figure 4 (modified from [56]). This unit is a progradational wedge on the outer shelf and thins into a distal drape (less than $10 \mathrm{msec}$ ) on the upper slope north of Tremiti Islands. Further north of the mapped area, it correlates with the paleo-Po prodelta lowstand wedge, forming a progradational unit with a thickness $>200 \mathrm{~m}$ together with the lower TST unit (Figure 3C).

\section{Materials and Methods}

Data used herein include high-resolution (Chirp-Sonar) seismic profiles and sediment cores and boreholes that are part of a large database built during the last 20 years at CNR-ISMAR. In particular, this work refers to data acquired between 1997 and 2006 on board of R/V Urania of the CNR (Italian National Research Council). Seismic data acquired during this period sum to more than $10,000 \mathrm{~km}$ of Chirp-Sonar seismic profiles densely covering the Italian Adriatic margin.

Chirp-Sonar profiles were shot from 16 hull-mounted transducers, using a $2-7 \mathrm{kHz}$ sweepmodulated bandwidth (equivalent to a $3.5 \mathrm{kHz}$ profiler) that allows vertical resolution in the order of $50 \mathrm{~cm}$ and penetration up to $80-100 \mathrm{~m}$. Track-line positioning was based on D-GPS navigation, assuring a position accuracy of $\sim 10 \mathrm{~m}$, and transformed to geographic coordinates referred to the WGS84 datum. Given the shallow depth investigated and the prevalently fine-grained composition of sediments, a constant sound velocity of $1500 \mathrm{~m} / \mathrm{s}$ in the water column and sediment was assumed for time-depth conversion.

Seismic data were integrated with sedimentological, chronostratigraphic, and biostratigraphic data (tephra layers, isotope curves, pollen spectra, ${ }^{14} \mathrm{C}$ analyses, foraminifera abundance) from 
sediment cores [70,76-78]. Sediment cores were collected using both gravity and piston corers with variable barrel length (3-20 m). In addition, a $72 \mathrm{~m}$ borehole in the Central Adriatic (drilled within the frame of "PROMESS 1" European Project) allowed for the continuous recovery of deposits recording the last $370 \mathrm{ky}[58,60]$. Part of this calibrated seismic dataset is herein re-analyzed to focus on the origin and preservation of TSR deposits on the South Adriatic outer shelf, an issue to date unexploited in previous works. Isochronopachs of the TSR (Figure 6) are reconstructed and used as the basis for discussing their lateral extent and thickness; depocenter distribution is then compared with the variability of seismic-stratigraphic and lithological characters, as derived by integrating seismic profiles with a set of six short gravity cores (Figure 7). Two of these cores reached the TSR in areas of maximum thickness and relief (COS-C10 and COS-C14); the other four cores penetrated the deposits where TSR deposits thin landward (COS-C11), seaward (YD-C13), and laterally (COS-C9 to the north and COS-C15 to the south) along the shelf margin (Figure 6).

Coring of the thicker (and coarser-grained) depocenter was limited by reduced penetration, due to which the recovered core sample was less than $1 \mathrm{~m}$ in length. Conversely, where thickness and grain-size diminished, penetration was more than $3 \mathrm{~m}$, locally allowing to recover also sediment of the underlying units of the last glacial LST and falling stages (FST).

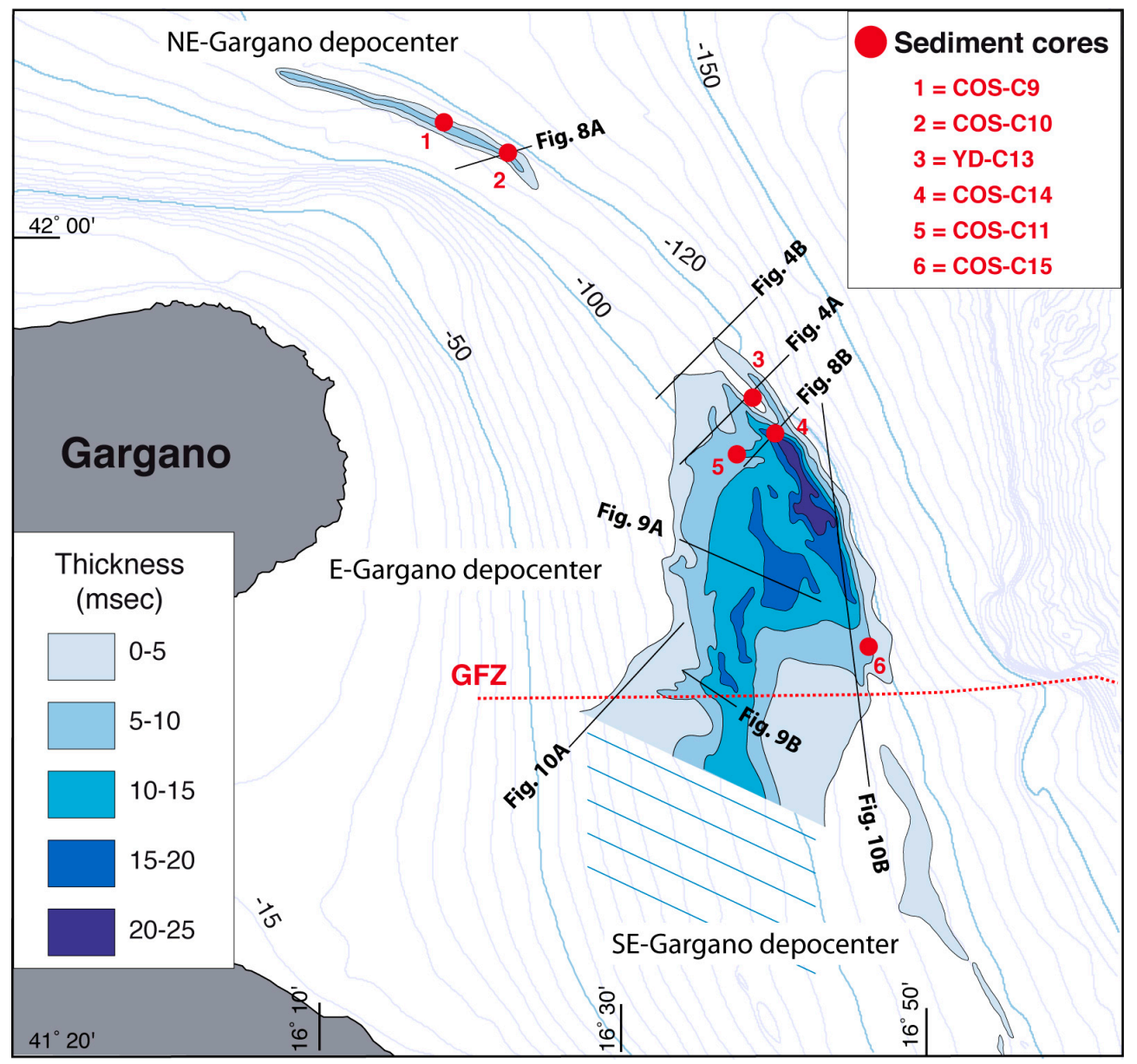

Figure 6. Isochronopachs of the early TST in the South Adriatic ( $1 \mathrm{msec} \cong 0.75 \mathrm{~m}$ in the investigated interval). Three separate depocenters are recognized NE, E and SE of Gargano Promontory, each comprising linear, contour-parallel deposits (between -100 and $-120 \mathrm{~m}$ ). The NE and SE depocenters are confined to the shelf edge, whereas the E-Gargano depocenter extends landward throughout a set of back-stepping deposits that progressively reduce their linear shape and ridged morphology. (Location of cores and seismic profiles is also reported; GFZ = Gondola Fault Zone; the oblique pattern indicates the area not covered by data used in this study). 


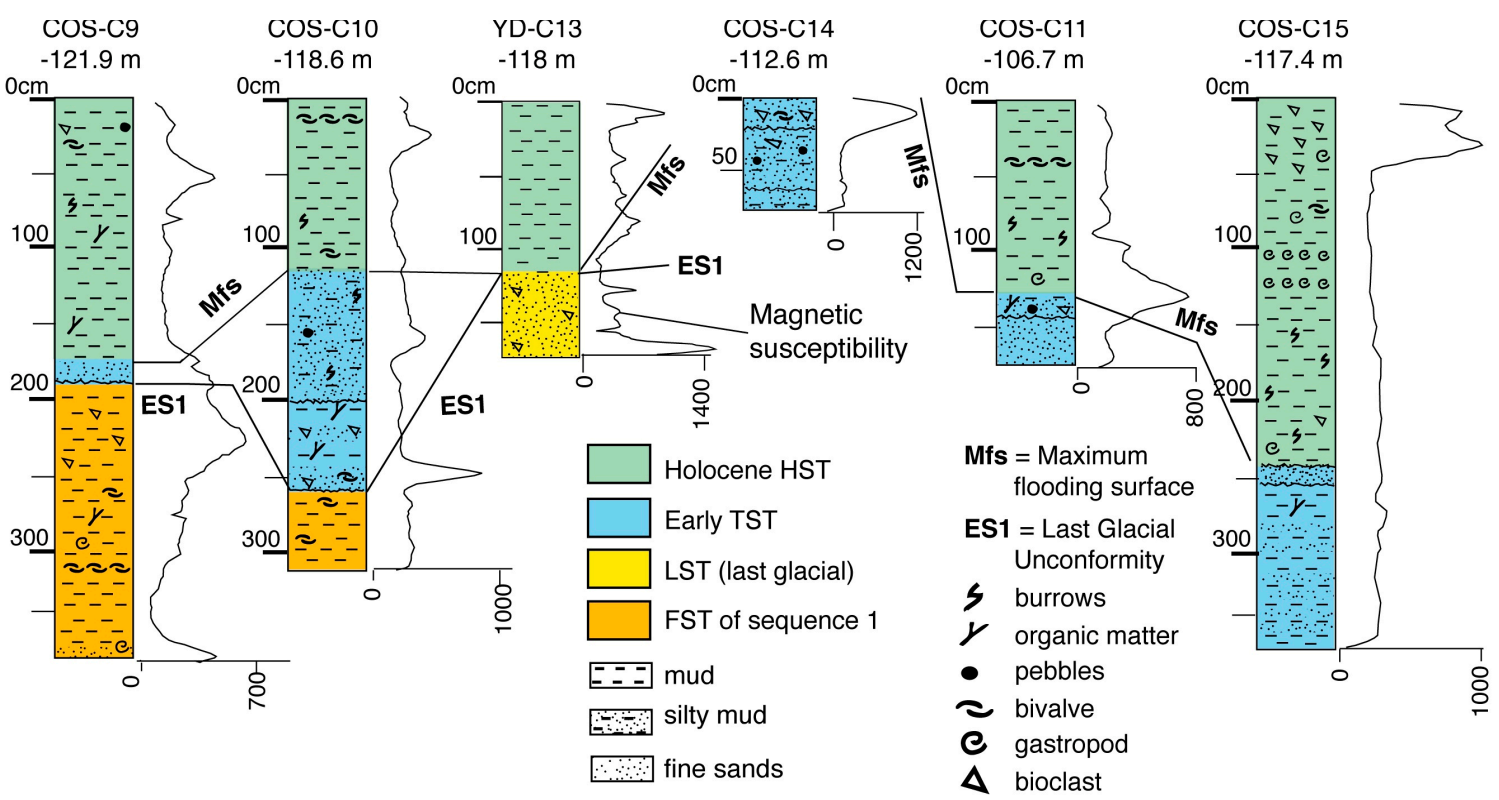

Figure 7. Lithologic composition of short sediment cores that reached the TSR on the South Adriatic shelf (location in Figures 1 and 6; description and details in Section 4.3). Magnetic susceptibility was used to crosscheck identification and correlation of key stratigraphic surfaces. Systems tracts definition is based on seismic-stratigraphic analysis and calibration with chronostratigraphic data (see Section 3).

\section{Results}

\subsection{Depocenter Distribution of the Early Transgressive (TST) and Transgressive Sand Ridges (TSR)}

Stratigraphical and lateral continuity of the early TST are higher to the north, close to the MAD, where this unit thickens under the more direct influence of sediment supplied by the paleo-Po River (Figure 3B,C). South of the MAD, and away from the influence of a large deltaic source, the early TST unit varies from a few meters thick, flat-tabular unit, to a thin draping lag; locally, it occurs also as a subtly lenticular, patchy deposit filling erosional scour of ES1 unconformity (Figure 3D). At places, it is extensively missing on the outermost shelf (Figure 1), where late TST and HST deposits lay directly on the ES1 unconformity.

In the South Adriatic, the early TST is fragmented along three distinct depocenters located NE, E, and SE of Gargano Promontory; these depocenters are separated by areas of non-deposition or non-preservation (Figure 6). Locally, and close to the shelf edge (essentially between -110 to $-120 \mathrm{~m}$ ), depocenters consist of linear deposits referable to as "transgressive sand ridges" because of their overall shape, morphology, internal architecture, and lithological composition (see next Sections).

The E-Gargano depocenter is the largest and the only in which deposits have been mapped up to a depth of ca. $80 \mathrm{~m}$, landward of the shelf-edge TSR. Maximum thickness of the E-Gargano shelf edge TSR is ca. 18-20 m (20-25 msec in Figure 6). Thickness decreases landward, along three less elongated and mounded depocenters (up to 10-15 m thick; 15-20 msec in Figure 6) aligned NE-SW. All around these mounds, early TST deposits thin and pass laterally and vertically (at depths shallower than 80-90 m) to younger middle TST deposits. In the NE-Gargano depocenter, TSR deposits attain maximum thickness up to $5 \mathrm{~m}$, forming a ca. $30 \mathrm{~km}$ long and 2-3 km wide, linear depocenter. Thickness is less than 3-4 $\mathrm{m}$ along the SE-Gargano depocenter-in fact a flatter, draping unit with no significant relief morphology (Figure 6).

By comparing the distribution of the TSR depocenters (Figure 6) with that of the last glacial LST deposits (Figures 1 and 5), it is evident that the TSR develop on top and slightly landward of the LST (where this unit is preserved), actually marking the turn-around point from lowstand to rising sea level (at the closing of the LGM, between 26 and $19 \mathrm{ka} \mathrm{BP}$ according to [60]). 


\subsection{Seismic Stratigraphy of the Early TST and TSR Deposits}

In the South Adriatic, the seismic facies of the early TST varies from high-angle oblique-clinoform to chaotic/opaque seismic reflections (Figure 8). The oblique-clinoform geometry is more evident where deposits are thicker and form the shelf edge TSR (Figures 6 and 8). As the deposits progressively thin and flatten landward and laterally, the chaotic/opaque facies prevail (Figure 9).

The thicker TSR deposits along the E-Gargano depocenter consist of oblique clinoforms with $7^{\circ}-10^{\circ}$ dipping fore-sets and irregular (erosional) top-set forming a prominent seafloor relief (Figure 8). The fore-sets attain a seaward concave shape, whereas the top-sets may preserve a subtle landward sloping, indicative of seaward increasing clinoform height as progradation progressed (Figure 8A). The shelf-edge high-angle prograding deposits pass landward to opaque seismic units with mounded morphology (Figure 9), alternating with flat-tabular deposits in areas where the shelf is affected by anticline deformation along the GFZ (Figure 10). These deposits fill the depressions around the anticline flanks, locally incised by channels cutting into ES1 (Figure 10A), and thin towards the anticline crest (Figure 10B). These channels are likely part of an incised valley system known from previous studies to have been cut during the last glacial sea level fall and lowstand, and partly filled during the ensuing sea level rise [75,79].

The morphological relief of the E-Gargano shelf-edge TSR gradually decreases northward, where a thin TSR lays directly above the LST wedge and is characterized by seismically opaque to faintly clinoform reflections, (Figure 4A). Both the TSR unit and the LST are affected by marked erosion and incisions. Along the profile in Figure 4 , the incision has a width $>1 \mathrm{~km}$ and a depth $<10 \mathrm{~m}$; two smaller incisions (100-500 $\mathrm{m}$ wide and 1 to less than $5 \mathrm{~m}$ deep) can be observed seaward, draped by the same HST veneer that covers the larger channel and the TSR (Figure 4A). Further north, seismic line YD8 evidences how TSR deposits are absent, and incision broadens as it becomes shallower (Figure 4B).

The narrow TSR along the NE-Gargano depocenter also shows internal high-angle clinoforms growing slightly steeper seaward, where the top-sets form a pronounced relief on the seafloor despite the draping by late Holocene HST deposits (Figure 8A). In contrast with the E-Gargano TSR, however, the progradational wedge thins and abruptly pinches-out landward, resulting in the absence of back-stepping TST deposits on the middle shelf. The SE-Gargano depocenter, although elongated, is not characterized by internal clinoforms and lacks of mounded or ridge morphology; on the contrary, it appears as a draping lag deposit.

In summary, the TSR in the South Adriatic shows three different stratigraphic patterns in terms of external shape and internal architecture: (1) asymmetric ridge, with a steeper seaward flank in correspondence of the fore-sets of relatively high-angle progradational clinoforms that correlate landward with gently mounded units extending on distances up to $30 \mathrm{~km}$ (e.g., the main E-Gargano depocenter); (2) similar asymmetric ridge consisting of steep progradational clinoforms, but abruptly pinching landward onto the ES1 erosional unconformity (e.g., the NE-Gargano depocenter); and (3) thin, overall planar lags contouring the ridge and mounds of the E-Gargano depocenter, and forming in all the SE-Gargano depocenter.

\subsection{Lithology of TSR}

Because sedimentation in the Adriatic has been largely mud-dominated since the Middle-Late Pleistocene $[4,57,67,80]$, the transgressive sand ridges, although retaining a fine-grained component, are remarkable for their relatively sandy composition. On the thicker clinoform top-sets of the E-Gargano TSR, core COS-C14 penetrated less than $1 \mathrm{~m}$, at ca. $113 \mathrm{~m}$ water depth (Figures 6-8). The recovered sediment consists of thick sandy beds separated by sharp erosional contacts, with sparse pebbles, silty matrix, and abundant cm-scale bioclasts (essentially bivalve fragments). 

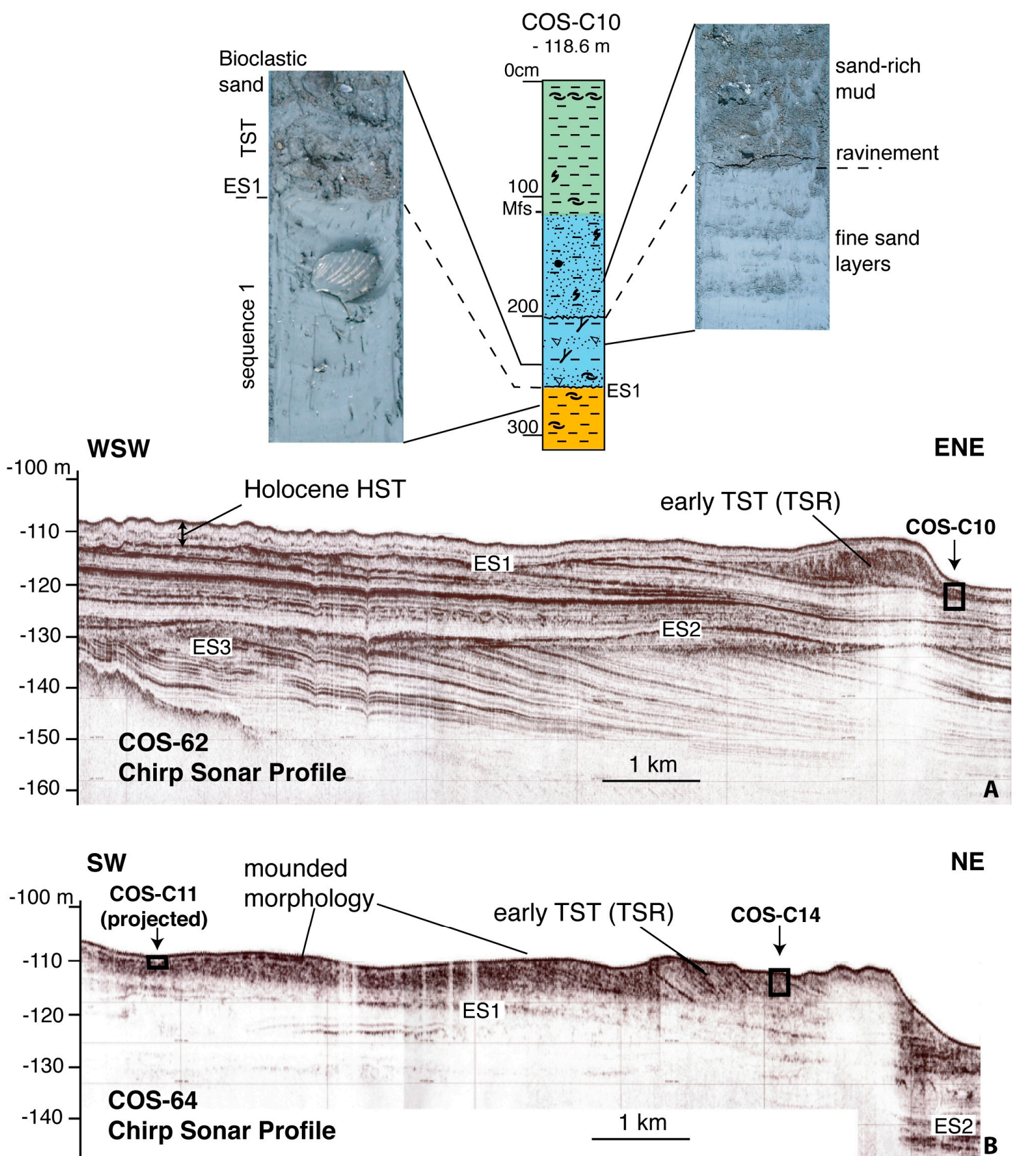

Figure 8. Seismic profiles (location in Figures 1 and 6) showing the ridge-like shape and internal progradational geometry of TSR from the NE-Gargano ((A) modified from [56]) and E-Gargano depocenters (B). Note the abrupt pinch-out of the NE-Gargano TSR compared to the mounded deposits extending landward (SW) of the E-Gargano shelf edge clinoform. Position of cores COS-C10 (with details of cored TSR interval) and COS-C14 is reported (see also Figure 7).

A similar result, in terms of poor penetration/recover of TSR deposits, was obtained with core COS-C11, which penetrated the northward thinning part of the mound backing the TSR cored by COS-C14, at ca. $107 \mathrm{~m}$ water depth (Figures 6-8). Considering the ca. $1.75 \mathrm{~m}$ of recovered sediment, the upper $1.25 \mathrm{~m}$ is composed of unconsolidated late Holocene HST muds. Below and across a neat (though non-erosional) surface, $50 \mathrm{~cm}$ of the TSR sediment are found, of which the uppermost $20 \mathrm{~cm}$ are composed of bioclastic sand with pebbles; a sharp erosional surface separates this interval from the lower $30 \mathrm{~cm}$, composed of sands with no pebbles or bioclasts (Figure 7). 

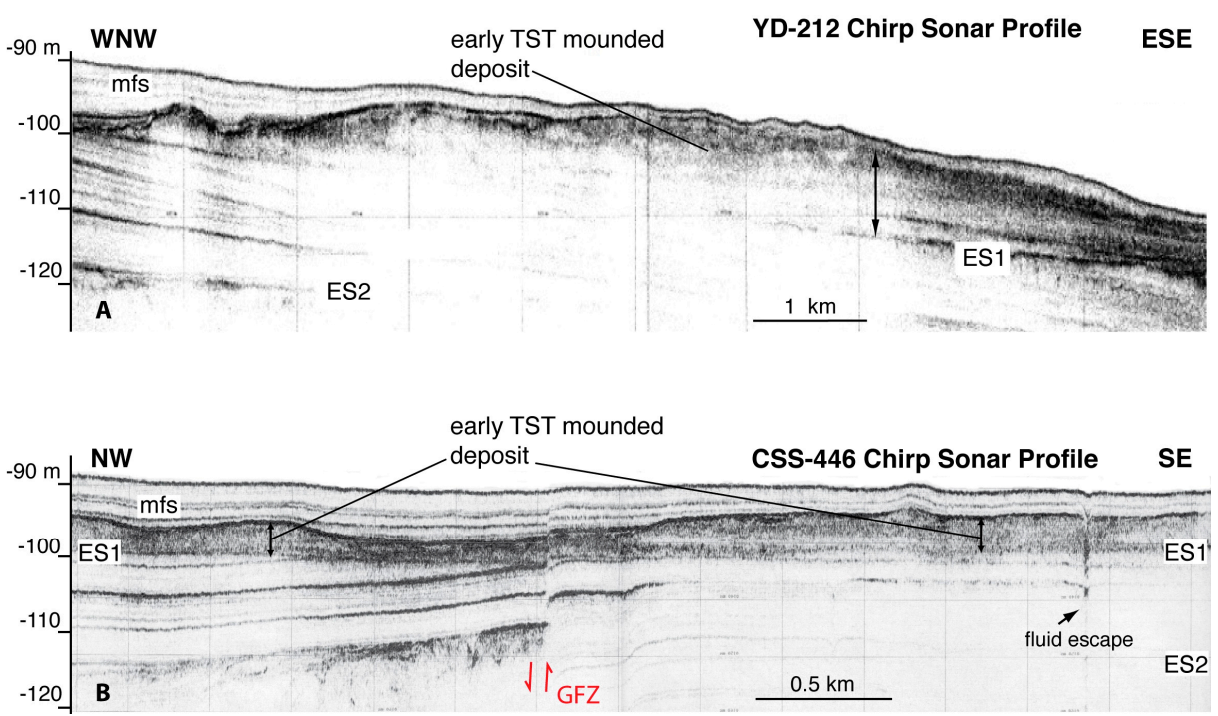

Figure 9. Seismic profiles (location in Figures 1 and 6) showing the opaque seismic units with mounded morphology that represent early TST deposits landward of the E-Gargano shelf edge TSR. From NE (A) to SW ((B) modified from [51]), the mounded morphology and relief attenuate below a progressively thicker cover of late TST and HST deposits. Further landward, the early TST deposits pass laterally and vertically to the middle TST (area not mapped in Figure 6). Profile CSS-446 (A) shows displacement along the GFZ, also responsible for differential uplift/lowering of shelf sectors.

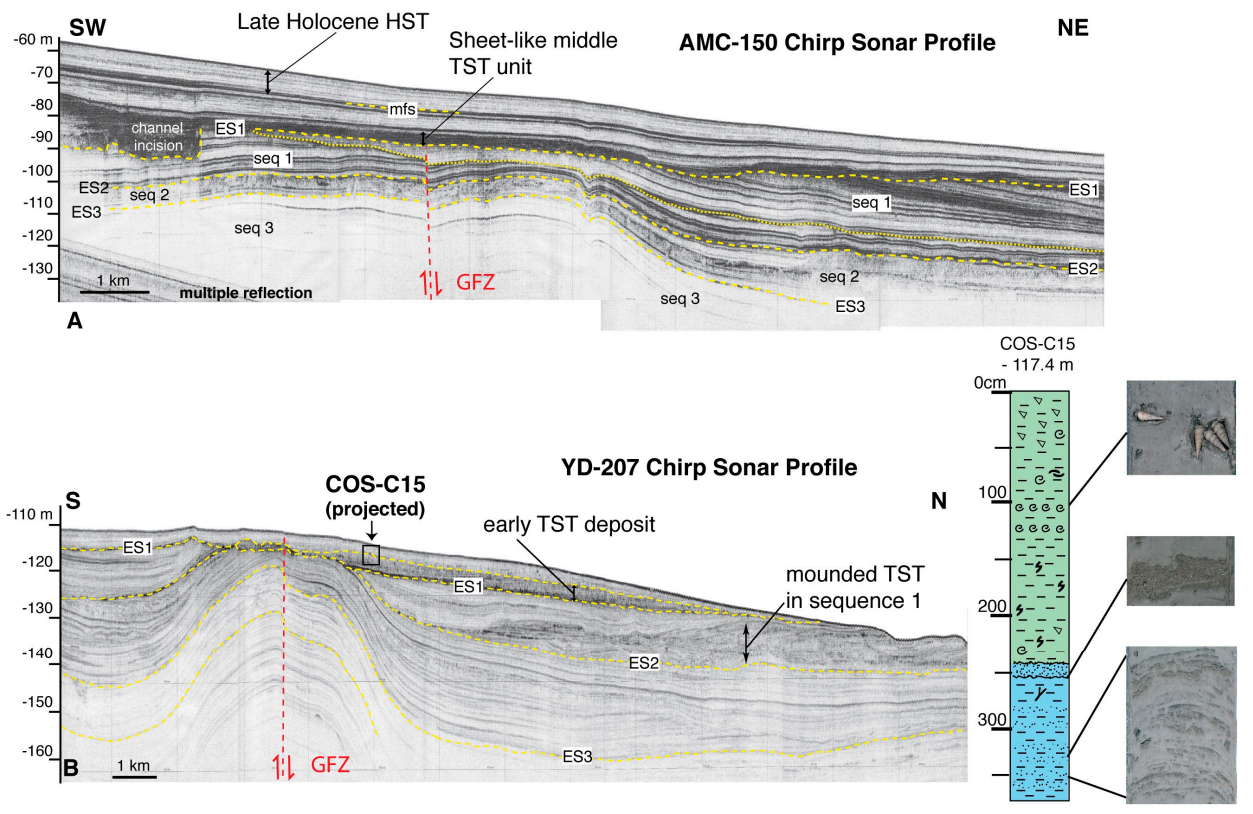

Figure 10. Seismic profiles (location in Figures 1 and 6) evidencing the absence of mounded TST deposits in shelf sectors shallower than $-90 \mathrm{~m}$ ((A) modified from [51]), and the southward thinning/flattening of TSR deposits along the shelf edge ((B) modified from [44]). AMC-150 seismic profile (A) shows an opaque TST unit that correlates landward with middle TST deposits, although directly overlaying ES1 unconformity (affected by channel incision along the south-eastern flank of the anticline). In YD-207 seismic profile (B), early TST deposits that correlate with TSR at north form a flat-tabular unit terminating against the flank of the anticline, by this marking their southward limit. A detail of the core that reached these deposits is shown (see Figures 6 and 7). Note the mounded-irregular TST unit at the base of sequence 1 (on top of ES2), interpreted as older equivalent of TSR mounded deposits. 
Further south, core COS-C15 recovered $3.75 \mathrm{~m}$ of transgressive deposits, at ca. $117 \mathrm{~m}$ water depth (Figures 6, 7 and 10). The uppermost $2.40 \mathrm{~m}$ show the typical facies of the Holocene HST, consisting of bioturbated mud with biosomes and bioclasts, although some silt is present. An erosional contact separates this interval from the TSR deposit, consisting of a sand layer ca. $10 \mathrm{~cm}$ thick, with erosional base above ca. $1.2 \mathrm{~m}$ of pelites with silt and fine sand intercalations. North of the site of core COS-C14, an attempt was made at sampling sediment at the base of the incision cutting TSR and LST deposits (Figure 4A). Here, core YD-C13 recovered $1 \mathrm{~m}$ of mud with some silt and sand content, followed down-core by $75 \mathrm{~cm}$ of bioclastic sands with silty-muddy matrix (Figures 4, 6 and 7).

Core COS-C10 penetrated over $3 \mathrm{~m}$ in correspondence of the toe-sets of the NE-Gargano TSR, at $119 \mathrm{~m}$ water depth (Figures 6-8). Below ca. $1.3 \mathrm{~m}$ of unconsolidated late Holocene HST mud, ca. $1.5 \mathrm{~m}$ of TSR sediment was recovered. Lithology and facies throughout the upper ca. $90 \mathrm{~cm}$ of this interval are the same as observed in COS-C14 and COS-C11; a sharp erosional surface then marks the transition to a $60 \mathrm{~cm}$-thick silty mud interval with intercalated sand layers. The base of the TSR is at ca. $2.10 \mathrm{~m}$, where a second erosional surface marks the contact with consolidated muddy sediment of the distal FST deposits within sequence 1 (Figures 6-8). Despite the difference in thickness, the TSR facies in core COS-C10 is very similar to that observed in COS-C15. Further north, and in slightly deeper water (ca. $-122 \mathrm{~m}$ ), core COS-C9 recovered $3.70 \mathrm{~m}$ of sediment in which the TSR is recorded only by a ca. $15 \mathrm{~cm}$ thick sand layer, at ca. $1.75 \mathrm{~m}$ core depth (Figures 6 and 7 ). This interval is topped by bioturbated late Holocene HST mud, and lays erosionally on bioclastic mud with sparse silt layers of sequence 1 (FST).

\section{Discussion}

\subsection{Factors Controlling Deposition and Preservation of TSR}

Previous studies report the absence of the lower TST unit in the South Adriatic, suggesting its erosion during a sea level fall associated with the Younger Dryas event, or reduced deposition during the early phase of sea level rise [66]. In this work, transgressive deposits have been identified on the outer shelf in a stratigraphic position that is above the lowstand unit and below the middle TST defined by [66]. These early transgressive deposits locally show ridged morphology, linear development, and relatively coarse composition, by which they are comparable to a variety of transgressive sand ridges described worldwide. The stratigraphic relationship between the South Adriatic transgressive sand ridges (TSR) and other transgressive deposits forming during the post-glacial sea level rise is summarized in Figure 11.

The South Adriatic TSR deposits form three detached depocenters displaying variable thickness and overall shape. The ridged morphology and high-angle clinoform progradation are typical features only of deposits at the shelf-edge, at 100-120 m water depth (except for the SE-Gargano depocenter, where the relief of deposits has not survived transgressive erosion). The E-Gargano depocenter is the main one, and the only extending at depths shallower than 90-100 m. Depocenter migration at shallower depths is accomplished by mound-shaped deposits (Figure 9), seismically opaque and with less evidence of internal clinoforms compared to the outer shelf ridge-shaped deposits. These mounds show an overall back-stepping trend that parallels the direction towards which the shelf widens (Figure 6).

The partitioning of the TSR deposits reflects the variable deposition/preservation potential of near-shore deposits along the Adriatic shelf, depending on both regional and local factors. Among the regional factors, the change in overall structural setting, from Central to South Adriatic (Figure 2), determines differences in shelf gradients and topography, which in turn influence the overall wave/current regime and resulting erosion during sea level change and shoreline shifts [81]. Because of the mud-prone sedimentation in the Adriatic, deposition and preservation of TSR deposits largely depended on local fonts of sandy sediment allowing the growth of progradational units capable of surviving (even partially) the subsequent transgressive erosion. 


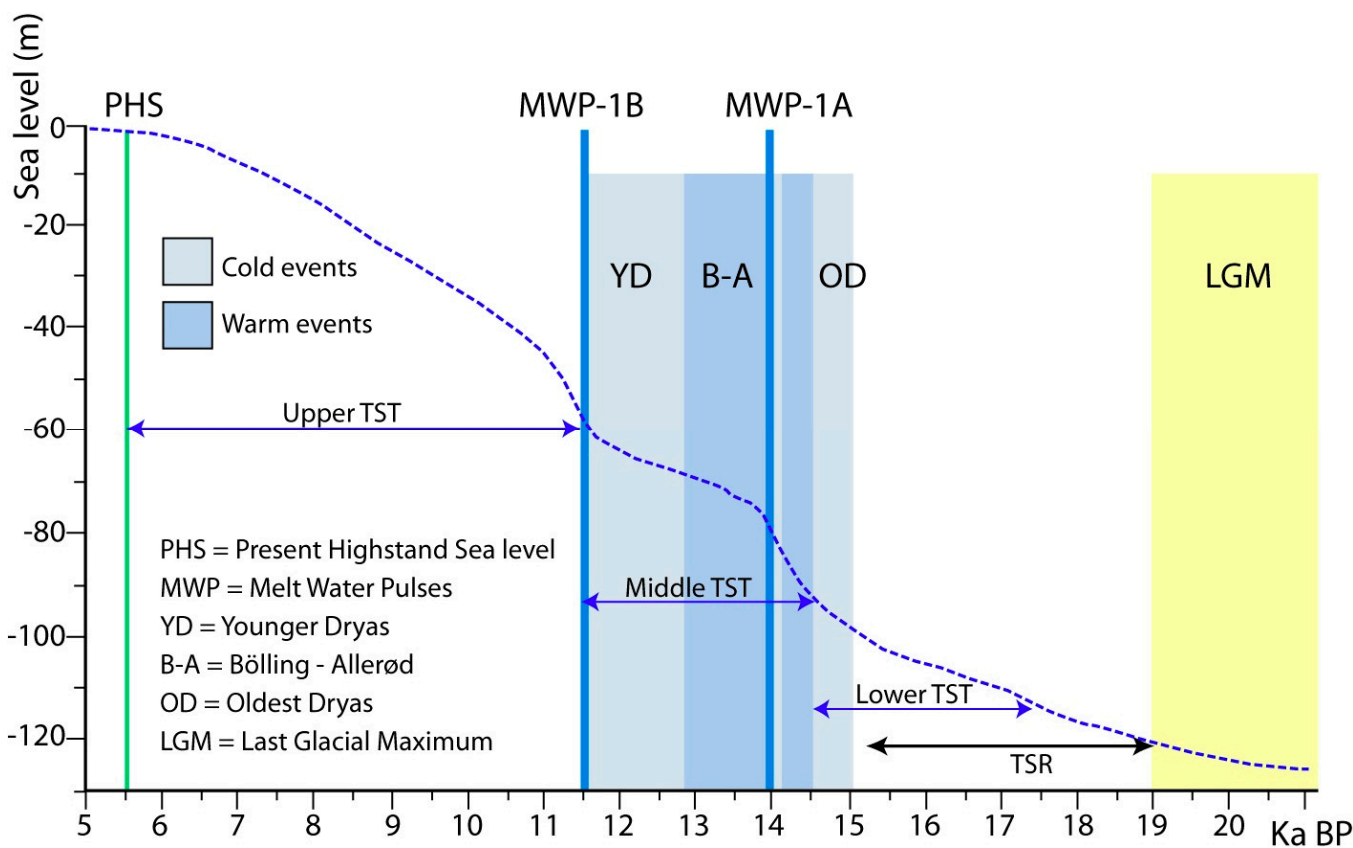

Figure 11. The relationship between climate events controlling the shape of the sea level curve and the time of deposition of TST units in the Central Adriatic (blue double arrows) has been reconstructed by $[45,73]$, and extended to the South Adriatic by [66]. The interval of deposition of the TSR deposits is constrained on the basis of their bathymetric depth and stratigraphic position with respect to other TST units and the LST deposits of the Last Glacial Maximum (LGM).

At the onset of the post-glacial sea level rise, morpho-tectonic relief and higher gradients on the South Adriatic shelf margin enhanced transgressive (ravinement) erosion of older (lowstand) shoreline deposits, in contrast with their flooding being favored in the subsiding Central Adriatic shelf (Figure 12). Reworking of pre-existing near-shore lowstand deposits provided the local source of coarse sediment, independent of fluvial input (essentially confined to the northern area of the basin). This local reworking-supply mechanism can be envisaged as analogous, although reversed, to the "cannibalization" of pre-existing shoreline deposits during sea level fall and "forced-regression" [82].

As a consequence, TSR and LST progradational units appear lithologically similar, and the outer shelf area where TSR deposits show a neat ridge-like morphology is the same where proximal/progradational deposits of the last glacial LST are found, though intensely eroded. Accordingly, TSR deposits are not present in the area of the SE-Gargano depocenter, where sediment bypassing precluded the origin of an outer shelf prograding lowstand wedge [83]. They are also absent on the Central Adriatic shelf, where the lowstand shelf wedge is present but the overall regional subsidence trend resulted in more gentle shelf gradients and morphology: these favored a rapid drowning and limited marine (ravinement) erosion [58], by this hampering reworking and recycling of sands to form early transgressive near-shore deposits thick enough to preserve in the form of TSR (Figure 12(C1,C2)).

In correspondence to the NE-Gargano depocenter, higher shelf gradients at depths less than $110 \mathrm{~m}$ limited the landward extent of the TSR deposits, resulting in the typical narrow-linear trend, with no evidence of landward migration in the inner shelf sectors. In correspondence to the E-Gargano depocenter, instead, the landward back-stepping of mounded deposits is enhanced by a wider shelf with more gentle gradients except for sectors impacted by the GFZ. Most likely, back-stepping of mounded deposits was also favored by a local riverine source, as testified by sparse channel incision (Figure 10); in this view, the tabular to lens-shaped deposits (Figure 9) can be interpreted in terms of small prodelta lobe deposition. Interestingly, similar (though larger) deltaic lobes have been 
documented immediately south of E-Gargano TSR depocenter (area with oblique pattern in Figure 6), and related to an incised valley system feeding deltaic deposition during lowstand and early sea level rise (up to $15 \mathrm{ka} \mathrm{BP}$ ) [75].

(A)

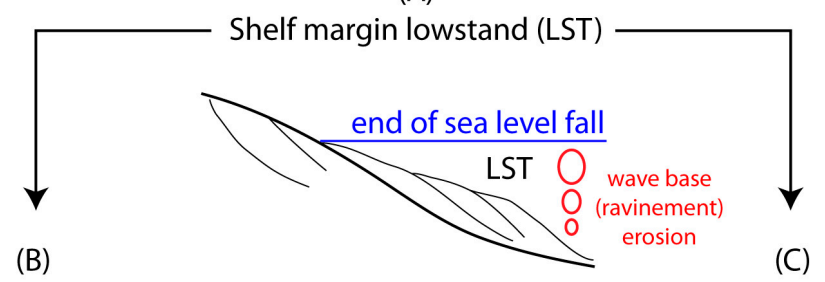

South Adriatic shelf tectonic relief, lower subsidence
Central Adriatic shelf lower relief, higher subsidence

onset of sea level rise
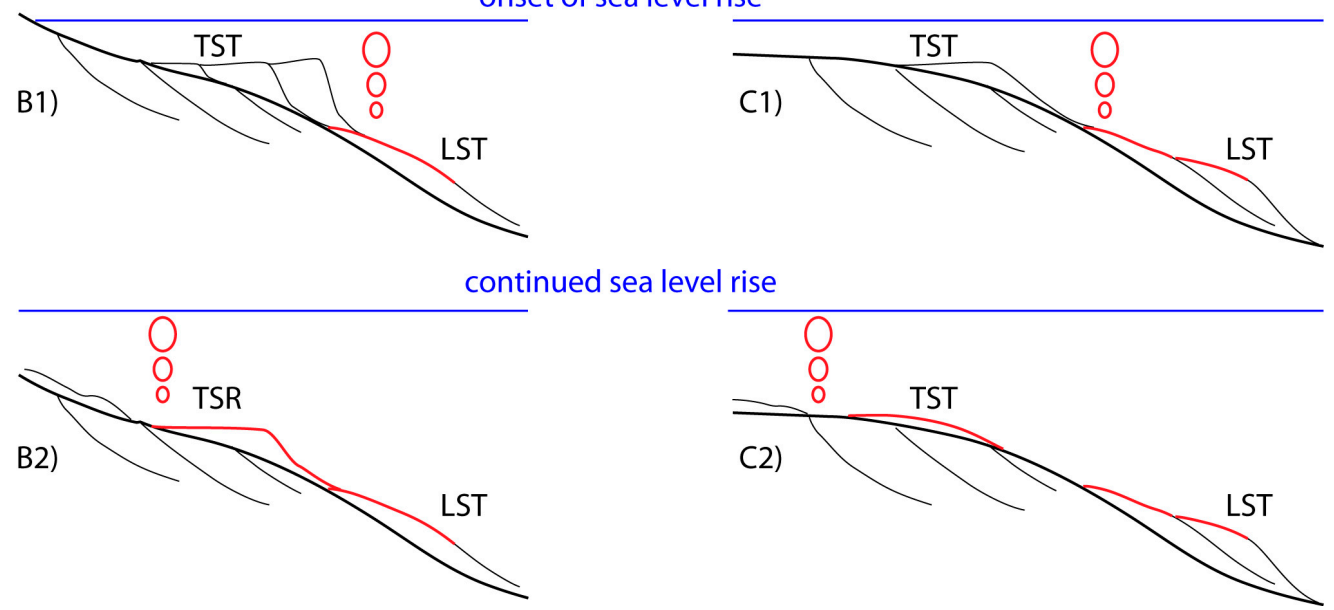

Figure 12. Simplified scheme representing differential deposition and preservation of the TSR deposits. Lowstand (LST) near-shore deposits (A) are differently reworked during transgression on the tectonically uplifted South Adriatic (B) and subsiding Central Adriatic margin (C). At the onset of sea level rise, LST deposits are more intensely eroded and reworked into early TST deposits in the South Adriatic, where higher gradients/relief enhance ravinement erosion and hamper rapid flooding of LST below wave base erosion (B1). On the subsiding Central Adriatic shelf margin, lower shelf gradients/relief enhance drowning and allow LST deposits to partly escape erosional reworking during transgression. This determines a reduced availability of coarse sediment, in turn resulting in a less developed early TST near-shore deposit (C1). As sea level rise continues, the early TST deposits also undergo transgressive (ravinement) erosion (B2,C2); however, only in the South Adriatic do the thicker units escape complete erosion and preserve their wedged shape, forming the shelf edge TSR (B2).

The smaller NE-SW back-stepping depocenters north of the deformed shelf sector (Figure 6) may reflect the presence of a secondary river branch departing from the main incised valley system documented in previous studies [75]. This secondary river could have bypassed (towards NE) the GFZ anticline, still growing during the last glacial cycle [44] and thus able to impinge the course of any paleo-river across the exposed South Adriatic shelf. The subtle tectonic relief may have acted as a nick-point controlling the seaward extent of major incision during sea level fall and lowstand, by this accounting for the lack of fluvial incision on the outer shelf, at depths beyond 70-80 $\mathrm{m} \mathrm{[75].}$

If ever a secondary stream departed from the main incised valley system, flowing north of the tectonic relief, it should have been completely drowned at the time that the shoreline reached the mouth of the main incised valley at 70-80 m water depth, ca. $15 \mathrm{ka} \mathrm{BP} \mathrm{[75].} \mathrm{At} \mathrm{this} \mathrm{time,} \mathrm{a} \mathrm{greater}$ part of the sediment conveyed by the incised valley debouched south of the GFZ. Here, this sediment sourced the deltaic lobes described by [75] (herein interpreted as transgressive rather than lowstand 
deposits as in [75]); accordingly, these southern lobes grew larger in thickness and extent compared to those deposited earlier by the secondary stream, north of the GFZ.

\subsection{Sequence-Stratigraphic Implications}

The shelf edge TSR deposits mark the end of lowstand deposition and the onset of landward building of a transgressive shoreline. This was favored in areas of greater availability of sand from reworking of older lowstand deposits. Further landward migration of transgressive shorelines, during the ensuing sea level rise, is recorded only by back-stepping prodelta lobes in a confined area, possibly sourced by a small stream flowing NE. During the sea level rise, the efficiency of this stream decreased, and ceased when the shoreline reached (around $15 \mathrm{ka}$ BP) the mouth of the main incised valley system from which it departed. These results deal with questions on the response of depositional systems at the turn-around point of a sea level cycle, and the degree to which the different systems tracts building up depositional sequences match (despite differences in the local environment) with distinct phases of sea level supposed to control sequence architecture [84-86].

Variable conditions during these transitions have profound impacts on the lateral and vertical distribution of sediment types both at the local and regional scale, ultimately resulting in the varied stratigraphic architecture of depositional sequences as observed in the stratigraphic record. In particular, the balance between relative sea level change and sediment supply (in the background of the diverse environmental contexts) affects a number of sequence-stratigraphic features-for instance, the sharpness of bounding surfaces, the stratigraphic/sedimentological break between successive systems tracts, or even the preservation or non-preservation of parts or of entire systems tracts $[87,88]$.

The Adriatic lowstand to transgressive transition provides an insightful example of such highly variable stratigraphic patterns. Lowstand to transgressive deposits built virtually continuously on the North-Central Adriatic shelf, under the influence of the paleo-Po River delta, whereas they progressively decouple to the south, causing an evident stratigraphic break marked by a significant change in depositional pattern (Figure 3). Around Gargano Promontory, this depositional break is marked by the TSR deposits rimming the shelf edge. With the exception of the North Adriatic barrier-lagoon systems, actually keeping up with, and migrating during the early to middle phase of the sea level rise [72], the South Adriatic TSR deposits represent the only near-shore, sand prone deposit surviving transgressive ravinement during the post-glacial sea level rise.

With respect to the plethora of patterns included in the general definition of "transgressive sand ridges" [1-18], the Adriatic deposits more closely resemble the two-fold scheme defined by [16], according to which a distinction is made between sand ridges resulting from transgressive reworking of shelf margin lowstand deposits (i.e., the shelf edge TSR) and sand ridges that are "transgressive in origin" (i.e., the back-stepping mounded deposits). In the Adriatic case, however, the shelf edge TSR are also considered "transgressive in origin", since they distinctively overlay the "transgressed" lowstand deposits, as the result of a later (transgressive) reworking and re-sedimentation process (Figure 12). Accordingly, the erosion surface at their top is interpreted as a ravinement surface, and the transgressive surface is made coincident with the basal ES1 unconformity (indeed overlain by TST deposits in the entire Adriatic basin).

\section{Concluding Remarks}

Sedimentation rates can be highly variable during lowstand to early transgression, and sand supply on the outer shelf may depend on riverine/deltaic sources or simply on the reworking of older shorelines deposits. Many examples of such reworked shoreline deposits have been documented on modern continental shelves, where they have been referred to as "transgressive sand ridges". In the Adriatic, similar transgressive sand ridges typically formed at the onset of the last post-glacial transgression. However, transgressive sand ridges are not present on the entire shelf drowned during this interval. This fact indicates that local environmental factors contribute to their formation and preservation. 
In this view, the variable morpho-tectonic setting along the Adriatic margin is considered responsible for the patchy occurrence of TSR, limited to the South Adriatic shelf. In contrast with an overall subsiding margin in the Central Adriatic (where TSR deposits are absent), the South Adriatic is characterized by tectonic uplift resulting in higher gradients and morphological relief; these features enhance transgressive reworking and recycling of older lowstand shoreline deposits, by this providing a local source of sandy sediment at the onset of the sea level rise. As the sea level rise progresses, favorable conditions for the deposition/preservation of landward back-stepping TST deposits persist only in the E-Gargano area. Here, landward migration of small deltaic lobes is likely afforded by the presence of a small riverine sediment source. In the lack of riverine or relict near-shore deposits, transgressive near-shore deposits are progressively cannibalized on the remaining shelf sectors during the early sea level rise (ca. between 19 and $15 \mathrm{ka} \mathrm{BP}$ ).

Although retaining a fine-grained component (the Adriatic being a largely mud-dominated basin), the TSR deposits represent the most sand-prone sediments that can be found in the South Adriatic outer shelf.

Acknowledgments: Data used in this work are the result of many oceanographic cruises on board R/V Urania of the CNR, leaded by ISMAR-CNR within European Projects EURODELTA (EVK3-CT-2001-20001), EUROSTRATAFORM (EVK3-CT-2002-00079) and PROMESS 1 (EVR-1-CT-2002-40024). I am grateful to A. Fontana and two anonymous reviewers for their stimulating comments and useful suggestions. I also thank the Editor and the Editorial Staff of Geosciences for their kind and timely assistance.

Conflicts of Interest: The authors declare no conflict of interest. The founding sponsors had no role in the design of the study; in the collection, analyses, or interpretation of data; in the writing of the manuscript, and in the decision to publish the results.

\section{References}

1. Emery, K.O. Relict sediments on continental shelves of the world. AAPG Bull. 1968, 52, 445-464.

2. Swift, D.J.P.; Holliday, B.; Avignone, N.; Shideler, G. Anatomy of a shore face ridge system, False Cape, Virginia. Mar. Geol. 1972, 12, 59-84. [CrossRef]

3. Field, M.E. Sand bodies on coastal plain shelves: Holocene record of the U.S. Atlantic inner shelf off Maryland. J. Sediment. Petrol. 1980, 50, 505-528.

4. Swift, D.J.P.; Field, M.E. Evolution of a classic sand ridge field: Maryland sector, North American inner shelf. Sedimentology 1981, 28, 461-482. [CrossRef]

5. Belknap, D.F.; Kraft, J.C. Preservation Potential of Transgressive Coastal Lithosomes on the U.S. Atlantic Shelf. Mar. Geol. 1981, 42, 429-442. [CrossRef]

6. Stride, A.H.; Belderson, R.H.; Kenyon, N.H.; Johnson, M.A. Offshore tidal deposits: Sand sheet and sand bank facies. In Offshore Tidal Sands: Processes and Deposits; Stride, A.H., Ed.; Chapman \& Hall: New York, NY, USA, 1982; pp. 95-125.

7. Boyd, R.; Penland, S. Shoreface translation and the Holocene stratigraphic record: Examples from Nova Scotia, the Mississippi Delta and eastern Australia. Mar. Geol. 1984, 60, 391-412. [CrossRef]

8. Diaz, J.I.; Maldonado, A. Transgressive sand bodies on the Maresme continental shelf, Western Mediterranean Sea. Mar. Geol. 1990, 91, 53-72. [CrossRef]

9. McBride, R.A.; Moslow, T.F. Origin, evolution and distribution of shoreface sand ridges, Atlantic inner shelf, U.S.A. Mar. Geol. 1991, 97, 57-85. [CrossRef]

10. Field, M.E.; Trincardi, F. Regressive coastal deposits on Quaternary continental shelves: Preservation and legacy. In From Shoreline to Abyss: Contributions in Marine Geology in Honour of Francis Parker Shepard; Osborne, R.H., Ed.; SEPM, Spec. Publ.: Tulsa, OK, USA, 1991; Volume 46, pp. 107-122.

11. Wagle, B.G.; Veerayya, M. Submerged sand ridges on the western continental shelf off Bombay, India: Evidence for Late Pleistocene-Holocene sea-level changes. Mar. Geol. 1996, 136, 79-95. [CrossRef]

12. Chiocci, F.L.; Ercilla, G.; Torres, J. Stratal architecture of Western Mediterranean Margins as the result of the stacking of Quaternary lowstand deposits below glacio-eustatic fluctuation base-level. Sediment. Geol. 1997, 112, 195-217. [CrossRef]

13. Goff, J.A.; Austin, J.A.; Gulick, S.; Nordfjord, S.; Christensen, B.; Sommerfield, C.; Olson, H.; Alexander, C. Recent and modern marine erosion on the New Jersey outer shelf. Mar. Geol. 2005, 216, 275-296. [CrossRef] 
14. Lee, S.H.; Shinn, Y.J.; Lee, K.E.; Yoo, H.S. Depositional development of an isolated mound and adjacent area in the southern Yellow Sea during the last postglacial sea-level rise. Mar. Geol. 2009, 265, 19-30. [CrossRef]

15. Wu, Z.; Jin, X.; Zhou, J.; Zhao, D.; Shang, J.; Li, S.; Cao, Z.; Liang, Y. Comparison of buried sand ridges and regressive sand ridges on the outer shelf of the East China Sea. Mar. Geophys. Res. 2017, 38, 187-198. [CrossRef]

16. Berné, S.; Lericolais, G.; Marsset, T.; Bourillet, J.F.; De Batist, M. Erosional offshore sand ridges and lowstand shorefaces: Examples from tide- and wave-dominated environments of France. J. Sediment. Res. 1998, 68, 540-555. [CrossRef]

17. Ridente, D.; Petrungaro, R.; Falese, F.; Chiocci, F.L. Middle-Upper Pleistocene record of 100-ka depositional cycles on the Southern Tuscany continental margin (Tyrrhenian Sea, Italy): Sequence architecture and margin growth pattern. Mar. Geol. 2012, 326-328, 1-13. [CrossRef]

18. Durán, R.; Guillén, J.; Rivera, J.; Lobo, F.J.; Muñoz, A.; Fernández-Salas, L.M.; Acosta, J. Formation, evolution and present-day activity of offshore sand ridges on a narrow, tideless continental shelf with limited sediment supply. Mar. Geol. 2017. [CrossRef]

19. Swift, D.J.P.; Parker, G.; Lanfredi, N.W.; Perillo, G.; Figge, K. Shoreface connected sand ridges on American and European shelves: A comparison. Estuar. Coast. Mar. Sci. 1978, 7, 257-273. [CrossRef]

20. Busch, D.A. Prospecting for stratigraphic traps. AAPG Bull. 1959, 43, 2829-2843.

21. Sabins, F.F. Anatomy of a stratigraphic trap, Bisti field, New Mexico. AAPG Bull. 1963, 47, 193-228.

22. McCubbin, D.G. Cretaceous strike-valley sandstone reservoirs, northwestern New Mexico. AAPG Bull. 1969, 53, 2114-2140.

23. Lamb, G.M. Stratigraphy of the Lower Mancos Shale in the San Juan Basin. GSA Bull. 1968, 79, 827-854. [CrossRef]

24. Campbell, C.V. Depositional model-Upper Cretaceous Gallup beach shoreline, Ship Rock area, northwestern New Mexico. J. Sediment. Petrol. 1971, 41, 395-409.

25. Plint, A.G. Sharp-based shoreface parasequences and offshore bars in the Cardium formation of Alberta; their relationship to relative changes in sea-level. In Sea Level Changes-An Integrated Approach; Wilgus, C.K., Hastings, B.S., Kendall, C.G.S.C., Posamentier, H.W., Ross, C.A., Van Wagoner, J.C., Eds.; SEPM, Spec. Publ.: Tulsa, OK, USA, 1988; Volume 42, pp. 357-370.

26. Posamentier, H.W.; James, D.P.; Allen, G.P.; Tesson, M. Forced Regressions in a sequence stratigraphic framework: Concepts, examples, and exploration significance. AAPG Bull. 1992, 76, 1687-1709.

27. Walker, R.G.; Plint, A.G. Wave- and storm-dominated shallow marine systems. In Facies Models—Response to Sea Level Changes; Walker, R.G., James, N.P., Eds.; Geological Association of Canada: St. John's, NL, Canada, 1992; pp. 219-238.

28. Walker, R.G.; Bergman, K.M. Shannon Sandstone in Wyoming: A shelf ridge complex reinterpreted as lowstand shoreface deposits. J. Sediment. Petrol. 1993, 63, 839-851.

29. Walker, R.G.; Eyles, C.H. Topography and significance of a basin wide sequence bounding erosion surface in the Cretaceous Cardium Formation, Alberta, Canada. J. Sediment. Petrol. 1991, 61, 473-496.

30. Pattison, S.A.J.; Walker, R.G. Deposition and interpretation of long, narrow sand bodies underlain by a basin-wide erosion surface; Cardium Formation, Cretaceous Western Interior Seaway, Alberta, Canada. J. Sediment. Res. 1992, 62, 292-309.

31. Walker, R.G.; Wiseman, T.R. Lowstand shorefaces, transgressive incised shorefaces, and forced regressions; examples from the Viking Formation, Joarcam area, Alberta. J. Sediment. Res. 1995, 65, 132-141.

32. Berné, S.; Vagner, P.; Guichard, F.; Lericolais, G.; Liu, Z.; Trentesaux, A.; Yin, P.; Yi, H.I. Pleistocene forced regressions and tidal sand ridges in the East China Sea. Mar. Geol. 2002, 188, 293-315. [CrossRef]

33. Berné, S.; Jouet, G.; Bassetti, M.A.; Dennielou, B.; Taviani, M. Late Glacial to Preboreal sea-level rise recorded by the Rhône deltaic system (NW Mediterranean). Mar. Geol. 2007, 245, 65-88. [CrossRef]

34. Harrison, S.E.; Locker, S.D.; Hine, A.C.; Edwards, J.H.; Naar, D.F.; Twichell, D.C.; Mallinson, D.J. Sediment-starved sand ridges on a mixed carbonate/siliciclastic inner shelf off west-central Florida. Mar. Geol. 2003, 200, 171-194. [CrossRef]

35. Shinn, Y.J.; Chough, S.K.; Kim, J.W.; Woo, J. Development of depositional systems in the southeastern Yellow Sea during the postglacial transgression. Mar. Geol. 2007, 239, 59-82. [CrossRef]

36. Snedden, J.W.; Tillman, R.W.; Culver, S.J. Genesis and Evolution of a Mid- Shelf, Storm Built Sand Ridge, New Jersey Continental Shelf, U.S.A. J. Sediment. Res. 2011, 81, 534-552. [CrossRef] 
37. Zhang, X.; Ding, L.; Du, J.; Liu, D.; Liu, H. Sedimentary characteristics and controlling factors of shelf sand ridges in the Pearl River Mouth Basin, northeast of South China Sea. J. Nat. Gas Geosci. 2017, 2, 141-155. [CrossRef]

38. Jin, J.H.; Chough, S.K. Partitioning of transgressive deposits in the southeastern Yellow Sea: A sequence stratigraphic interpretation. Mar. Geol. 1998, 149, 79-92. [CrossRef]

39. Park, S.C.; Han, H.S.; Yoo, D.G. Transgressive sand ridges on the mid-shelf of the southern sea of Korea (Korea Strait): Formation and development in high-energy environments. Mar. Geol. 2003, 193, 1-18. [CrossRef]

40. Posamentier, H.W.; Allen, G.P. Variability of the sequence stratigraphic model: Effects of local basin factors. Sediment. Geol. 1993, 86, 91-109. [CrossRef]

41. Frignani, M.; Langone, L.; Ravaioli, M.; Sorgente, D.; Alvisi, F.; Albertazzi, S. Fine-sediment mass balance in the western Adriatic continental shelf over a century time scale. Mar. Geol. 2005, 222-223, 113-133. [CrossRef]

42. Brommer, M.B.; Weltje, G.J.; Trincardi, F. Reconstruction of sediment supply from mass accumulation rates in the Northern Adriatic Basin (Italy) over the past 19,000 years. J. Geophys. Res. 2009, 114, F02008. [CrossRef]

43. Ridente, D.; Trincardi, F. Eustatic and tectonic control on deposition and lateral variability of Quaternary regressive sequences in the Adriatic basin. Mar. Geol. 2002, 184, 273-293. [CrossRef]

44. Ridente, D.; Trincardi, F. Active foreland deformation evidenced by shallow folds and faults affecting late Quaternary shelf-slope deposits (Adriatic Sea, Italy). Basin Res. 2006, 18, 171-188. [CrossRef]

45. Maselli, V.; Hutton, E.W.; Kettner, A.J.; Syvitski, J.P.M.; Trincardi, F. High-frequency sea level and sediment supply fluctuations during Termination I: An integrated sequence-stratigraphy and modeling approach from the Adriatic Sea (Central Mediterranean). Mar. Geol. 2011, 287, 54-70. [CrossRef]

46. Royden, L.E.; Patacca, E.; Scandone, P. Segmentation and configuration of subducted lithosphere in Italy: An important control on thrust-belt and foredeep-basin evolution. Geology 1987, 15, 714-717. [CrossRef]

47. Argnani, A.; Favali, P.; Frugoni, F.; Gasperini, M.; Ligi, M.; Marani, M.; Mattietti, G.; Mele, G. Foreland deformational pattern in the Southern Adriatic Sea. Ann. Geophys. 1993, 36, 229-247.

48. Doglioni, C.; Mongelli, F.; Pieri, P. The Puglia uplift (SE Italy): An anomaly in the foreland of the Apennine subduction due to buckling of a thick continental lithosphere. Tectonics 1994, 13, 1309-1321. [CrossRef]

49. Argnani, A.; Frugoni, F. Foreland deformation in the Central Adriatic and its bearing on the evolution of the Northern Apennines. Ann. Geophys. 1997, 40, 771-780.

50. Bertotti, G.; Casolari, E.; Picotti, V. The Gargano Promontory, a contractional belt in the Adriatic plate. Terra Nova 1999, 11, 168-173. [CrossRef]

51. Ridente, D.; Fracassi, U.; Di Bucci, D.; Trincardi, F.; Valensise, G. Middle Pleistocene to Holocene activity of the Gondola fault zone (southern Adriatic foreland): Deformation of a regional shear zone and seismotectonic implications. Tectonophysics 2008, 453, 110-121. [CrossRef]

52. Argnani, A.; Rovere, M.; Bonazzi, C. Tectonics of the Mattinata fault, offshore south Gargano (southern Adriatic Sea, Italy): Implications for active deformation and seismotectonics in the foreland of the Southern Apennines. GSA Bull. 2009, 121, 1421-1440. [CrossRef]

53. Di Bucci, D.; Ridente, D.; Fracassi, U.; Trincardi, F.; Valensise, G. Marine paleoseismology from very high resolution seismic imaging: The Gondola fault zone (Adriatic foreland). Terra Nova 2009, 21, 393-400. [CrossRef]

54. Maselli, V.; Trincardi, F.; Cattaneo, A.; Ridente, D.; Asioli, A. Subsidence pattern in the central Adriatic and its influence on sediment architecture during the last 400 kyr. J. Geophys. Res. 2010, 115, B12106. [CrossRef]

55. Cattaneo, A.; Correggiari, A.; Langone, L.; Trincardi, F. The late-Holocene Gargano subaqueous delta, Adriatic shelf: Sediment pathways and supply fluctuations. Mar. Geol. 2003, 193, 61-91. [CrossRef]

56. Ridente, D.; Trincardi, F. Pleistocene "muddy" forced-regression deposits on the Adriatic shelf: A comparison with prodelta deposits of the late Holocene highstand mud wedge. Mar. Geol. 2005, 222-223, 213-233. [CrossRef]

57. Steckler, M.S.; Ridente, D.; Trincardi, F. Modeling of sequence geometry north of Gargano Peninsula by changing sediment pathways in the Adriatic Sea. Cont. Shelf Res. 2007, 27, 526-541. [CrossRef]

58. Ridente, D.; Trincardi, F.; Piva, A.; Asioli, A.; Cattaneo, A. Sedimentary response to climate and sea level changes during the past $\sim 400$ ka from borehole PRAD1-2 (Adriatic margin). Geochem. Geophys. Geosyst. 2008, 9. [CrossRef] 
59. Ridente, D.; Trincardi, F.; Piva, A.; Asioli, A. The combined effect of sea level and supply during Milankovitch cyclicity: Evidence from shallow-marine $\delta^{18} \mathrm{O}$ records and sequence architecture (Adriatic margin). Geology 2009, 37, 1003-1006. [CrossRef]

60. Piva, A.; Asioli, A.; Schneider, R.R.; Trincardi, F.; Andersen, N.; Colmenero-Hidalgo, E.; Dennielou, B.; Flores, J.-A.; Vigliotti, L. Climatic cycles as expressed in sediments of the PROMESS1 borehole PRAD1-2, central Adriatic, for the last 370 ka: 1. Integrated stratigraphy, Geochem. Geophys. Geosyst. 2008, 9, Q01R01. [CrossRef]

61. Chappell, J.; Shackleton, N.J. Oxygen isotopes and sea level. Nature 1986, 324, 137-140. [CrossRef]

62. Shackleton, N.J. Oxygen isotopes, ice volume and sea level. Quat. Sci. Rev. 1987, 6, 183-190. [CrossRef]

63. Bard, E.; Hamelin, B.; Fairbanks, R.G. U-Th ages obtained by mass spectrometry in corals from Barbados: Sea level during the past 130,000 years. Nature 1990, 346, 456-458. [CrossRef]

64. Rohling, E.J.; Fenton, M.; Jorissen, F.J.; Bertrand, P.; Ganssen, G.; Caulet, J.P. Magnitudes of sea level lowstands of past 500,000 years. Nature 1998, 394, 162-165. [CrossRef]

65. Lea, D.W.; Martin, P.A.; Pak, D.K.; Spero, H.J. Reconstructing a 350 kyr history of sea level using planktonic $\mathrm{Mg} / \mathrm{Ca}$ and oxygen isotopic records from a Cocos Ridge core. Quat. Sci. Rev. 2002, 21, 283-293. [CrossRef]

66. Pellegrini, C.; Maselli, V.; Cattaneo, A.; Piva, A.; Ceregato, A.; Trincardi, F. Anatomy of a compound delta from the post-glacial transgressive record in the Adriatic Sea. Mar. Geol. 2015, 362, 43-59. [CrossRef]

67. Trincardi, F.; Asioli, A.; Cattaneo, A.; Correggiari, A.; Langone, L. Stratigraphy of the late-Quaternary deposits in the Central Adriatic basin and the record of short-term climatic events. In Palaeoenvironmental Analysis of Italian Crater Lake and Adriatic Sediments (PALICLAS Project); Guilizzoni, P., Oldfield, F.L., Eds.; Memorie Dell'Istituto Italiano Di Idrobiologia; Istituto Italiano di Idrobiologia: Verbania Pallanza, Italy, 1996; Volume 55, pp. 39-64.

68. Pellegrini, C.; Maselli, V.; Cattaneo, A.; Gamberi, F.; Asioli, A.; Bohacs, K.M.; Drexler, T.M.; Trincardi, F. How to make a 350-m-thick lowstand systems tract in 17,000 years: The Late Pleistocene Po River (Italy) lowstand wedge. Geology 2017, 45, 327-330. [CrossRef]

69. Correggiari, A.; Trincardi, F.; Langone, L.; Roveri, M. Styles of failure in late Holocene highstand prodelta wedges on the Adriatic shelf. J. Sediment. Res. 2001, 71, 218-236. [CrossRef]

70. Trincardi, F.; Correggiari, A.; Roveri, M. Late Quaternary transgressive erosion and deposition in a modern epicontinental shelf: The Adriatic semi-enclosed basin. Geo-Mar. Lett. 1994, 14, 41-51. [CrossRef]

71. Correggiari, A.; Roveri, M.; Trincardi, F. Late Pleistocene and Holocene evolution on the North Adriatic Sea. Quat. Ital. J. Quat. Sci. 1996, 9, 697-704.

72. Storms, J.E.A.; Weltje, G.J.; Terra, G.J.; Cattaneo, A.; Trincardi, F. Coastal dynamics under conditions of rapid sea-level rise: Late Pleistocene to Early Holocene evolution of barrier-lagoon systems on the northern Adriatic shelf (Italy). Quat. Sci. Rev. 2008, 27, 1107-1123. [CrossRef]

73. Cattaneo, A.; Trincardi, F. The Late Quaternary Transgressive Record in the Adriatic Epicontinental Sea: Basin Widening and Facies Partitioning. In Isolated Shallow Marine Sand Bodies; Bergman, K.M., Snedden, J.W., Eds.; SEPM Spec. Publ.: Tulsa, OK, USA, 1999; Volume 64, pp. 127-146.

74. Moscon, G.; Correggiari, A.; Stefani, C.; Fontana, A.; Remia, A. Very-high resolution analysis of a transgressive deposit in the Northern Adriatic Sea (Italy). Alp. Mediterr. Quat. 2015, 28, 121-129.

75. Maselli, V.; Trincardi, F. Large-scale single incised valley from a small catchment basin on the western Adriatic margin (central Mediterranean Sea). Glob. Planet. Chang. 2013, 100, 245-262. [CrossRef]

76. Asioli, A. High resolution foraminifera biostratigraphy in the Central Adriatic basin during the last deglaciation: A contribution to the PALICLAS Project. In Palaeoenvironmental Analysis of Italian Crater Lake and Adriatic Sediments (PALICLAS Project); Guilizzoni, P., Oldfield, F.L., Eds.; Memorie Dell'Istituto Italiano Di Idrobiologia; Istituto Italiano di Idrobiologia: Verbania Pallanza, Italy, 1996; Volume 55, pp. 197-218.

77. Asioli, A.; Trincardi, F.; Lowe, J.J.; Oldfield, F. Short-term climate changes during the last Glacial-Holocene transition: Comparison between the Mediterranean and North Atlantic records. J. Quat. Sci. 1999, 4, 3732-3781.

78. Asioli, A.; Trincardi, F.; Lowe, J.J.; Ariztegui, D.; Langone, L.; Oldfield, F. Submillennial scale climatic oscillations in the central Adriatic during the late glacial: Palaeoceanographic implications. Quat. Sci. Rev. 2001, 20, 1201-1221. [CrossRef]

79. Maselli, V.; Trincardi, F.; Asioli, A.; Ceregato, A.; Rizzetto, F.; Taviani, M. Delta growth and river valleys: The influence of climate and sea level changes on the South Adriatic shelf (Mediterranean Sea). Quat. Sci. Rev. 2014, 99, 146-163. [CrossRef] 
80. Trincardi, F.; Correggiari, A. Quaternary forced regression deposits in the Adriatic basin and the record of composite sea-level cycles. Geol. Soc. Spec. Publ. 2000, 172, 245-269. [CrossRef]

81. Zecchin, M.; Ceramicola, S.; Gordini, E.; Deponte, M.; Critelli, S. Cliff overstep model and variability in the geometry of transgressive erosional surfaces in high-gradient shelves: The case of the Ionian Calabrian margin (southern Italy). Mar. Geol. 2011, 281, 43-58. [CrossRef]

82. Plint, A.G. High-frequency relative sea-level oscillations in the Upper Cretaceous shelf clastics of the Alberta foreland basin: Possible evidence for glacio-eustatic control? In Sedimentation, Tectonics and Eustasy; Macdonald, D.I.M., Ed.; IAS Spec. Publ.: Gent, Belgium, 1991; Volume 12, pp. 409-428.

83. Ridente, D.; Foglini, F.; Minisini, D.; Trincardi, F.; Verdicchio, G. Shelf-edge erosion, sediment failure and inception of the Bari Canyon on the Southwestern Adriatic Margin (Central Mediterranean). Mar. Geol. 2007, 246, 183-207. [CrossRef]

84. Burgess, P.M.; Hovius, N. Rates of delta progradation during highstands: Consequences for timing of deposition in deep-marine systems. J. Geol. Soc. 1998, 155, 217-222. [CrossRef]

85. Burgess, P.M.; Lammers, H.; van Oosterhout, C.; Granjeon, D. Multivariate sequence stratigraphy: Tackling complexity and uncertainty with stratigraphic forward modeling, multiple scenarios, and conditional frequency maps. AAPG Bull. 2006, 90, 1883-1901. [CrossRef]

86. Burgess, P.M.; Prince, G.D. Non-unique stratal geometries: Implications for sequence stratigraphic interpretations. Basin Res. 2015, 27, 351-365. [CrossRef]

87. Lobo, F.J.; Ridente, D. Stratigraphic architecture and spatio-temporal variability of high-frequency (Milankovitch) depositional cycles on modern continental margins: An overview. Mar. Geol. 2014, 352, 215-247. [CrossRef]

88. Ridente, D. Releasing the sequence stratigraphy paradigm. Overview and perspectives. J. Geol. Soc. 2016, 173, 845-853. [CrossRef]

(C) 2018 by the author. Licensee MDPI, Basel, Switzerland. This article is an open access article distributed under the terms and conditions of the Creative Commons Attribution (CC BY) license (http://creativecommons.org/licenses/by/4.0/). 